\title{
IMPROVING WELLINGTON REGION'S RESILIENCE THROUGH INTEGRATED INFRASTRUCTURE RESILIENCE INVESTMENTS
}

\author{
Vinod K. Sadashiva ${ }^{1}$, Richard L. Mowll' ${ }^{2}$, S.R. Uma ${ }^{3}$, S.L. Lin ${ }^{3}$, \\ David W. Heron ${ }^{3}$, Nick A. Horspool ${ }^{3}$, Mostafa Nayyerloo ${ }^{4}$, \\ James Williams ${ }^{5}$, Yasir Syed ${ }^{6}$, Robert Buxton ${ }^{3}$, Andrew B. King ${ }^{3}$, \\ Biljana Lukovic $^{3}$, Kelvin R. Berryman ${ }^{3}$ and Michele C. Daly ${ }^{3}$
}

(Submitted July 2020; Reviewed December 2020; Accepted April 2021)

\begin{abstract}
Infrastructure networks (e.g. transport, water, energy, telecommunications) support life and the economy of communities of all sizes. New Zealand has witnessed several damaging earthquakes in the last decade that provide a compelling case to accelerate building resilient infrastructures in the country, so we can minimize any adverse impacts from future earthquakes. One of the regions that is highly vulnerable to earthquakes is Wellington. With the region's population continually expanding and placing increasing demand on its ageing infrastructures, with limited redundancy in the networks, and with many of its assets close to and / or intersecting fault lines, a large earthquake in the region could be highly disruptive, potentially resulting in serious social and economic consequences. While it may not be possible to completely avoid the impacts, they can be reduced. This paper provides an overview of the process taken in delivering a Wellington Lifelines Group report that demonstrates how impacts from a future major earthquake can be reduced through integrated and targeted infrastructure resilience investments. To quantify the benefits that can be achieved by making the proposed investments, impact modelling on nine different lifeline utilities in the Wellington metropolitan area were conducted; the assessment approach taken, and results derived and their use to prioritise resilience investments, are shown in this paper for selected key networks. The time-stamped service outage maps and tables produced from this work formed an essential input to evaluate and demonstrate the impact of the proposed resilience initiatives on the regional and national economies.
\end{abstract}

\section{INTRODUCTION}

Lives and economies of communities of all sizes around the world are heavily dependent on lifeline utilities (e.g. transport, water, energy, telecommunications). They are complex systems where each network not only depends on components within its own network to function but also typically depend on services from other networks (e.g. water network is dependent on electricity for treating and pumping water, while fuel supply to suburbs is dependent on road access) to successfully deliver the services required by the end users. As can be expected, damage caused to a network can have a cascading impact on the services provided by other dependent networks and, if the affected services are not recovered quickly or continue to operate at reduced levels of service for a long period, it can result in serious social (e.g. habitability, liveability) and economic (e.g. regional GDP) consequences.

New Zealand has witnessed several damaging earthquakes in the last decade [1-7] that have tested the resilience of its built environment (Figure 1) and communities. The significant events to have affected the lifeline utilities during this period are the 2010-2011 Canterbury Earthquake Sequence (CES) and the $2016 \mathrm{M}_{\mathrm{w}} 7.8$ Kaikoura earthquake. The transient and permanent ground deformations generated by the earthquakes of CES, particularly the $M_{w} 6.222$ February 2011 and $M_{w} 6.013$ June 2011 earthquakes, caused a range of damage to many infrastructure assets (examples shown in Figure 1(a-c)). The
$2016 \mathrm{M}_{\mathrm{w}} 7.8$ Kaikōura earthquake caused widespread damage, with the landslides triggered by the earthquake severely damaging large sections of State Highway 1 and a key railway line [7] (Figure 1(d)), resulting in significant direct and indirect impacts due to the disrupted services (e.g. [8]). Events such as the above provide a compelling case to accelerate building resilient infrastructure in the country so we can minimize impacts from future natural hazard events. In fact, the need to build resilience is well recognised in New Zealand's legislative and policy framework, with drivers including the Civil Defence Emergency Management Act, the Local Government Act, the Resource Management Act, the National Infrastructure Plan etc. [9]. Towards this aim many lifeline organisations have made resilience investments that have been demonstrated to have helped reduce the impacts in recent events (e.g. [10]). However, many investments are often made independently with little-to-no consideration given to the resilience of interdependent networks that together collectively contribute to a region's resilience. The Wellington Lifelines Group (WeLG) recognised the need for this step-change and in 2016 initiated an integrated approach to increase the resilience of lifeline utility services provided to Wellington and the surrounding cities of Hutt City, Upper Hutt City, Porirua City and the Kāpiti Coast (in this paper, referred to as the Wellington metropolitan area). The integrated approach means that all the members of WeLG collaborated in the creation of this project.

\footnotetext{
${ }^{1}$ Corresponding Author, Senior Risk Engineer, GNS Science, Lower Hutt City, v.sadashiva@gns.cri.nz (Member)

2 Wellington Lifelines Group, New Zealand

${ }^{3}$ GNS Science, Lower Hutt City, New Zealand

${ }^{4}$ AON New Zealand

5 University of Canterbury, Christchurch, New Zealand

${ }^{6}$ Massey University, Wellington, New Zealand
} 

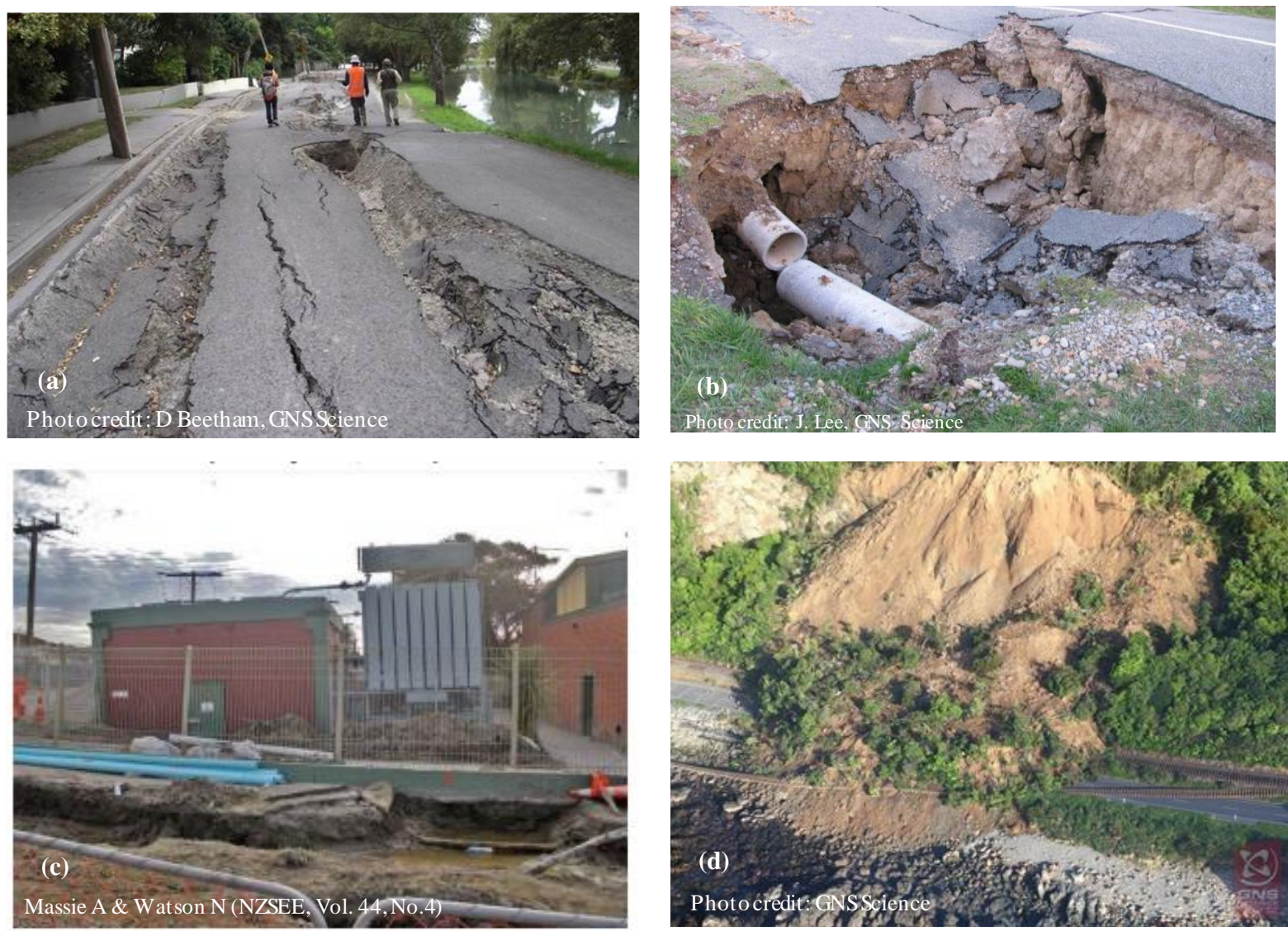

Figure 1: Examples of damaged infrastructure network assets from the 2010-2011 Canterbury earthquakes (Figures a-c) and the 2016 Kaikoura earthquake (Figure d).

The subject matter of this paper is WeLG's Programme Business Case (WeLG PBC) [9], a project that, through a combination of qualitative and quantitative assessment process demonstrated how economic disruption (both at regional and national level) of a major natural disaster in the region could be reduced by implementing an accelerated and phased programme of infrastructure resilience investments.

To quantify the potential economic benefits that can be achieved by investing in the region's infrastructure resilience, modelling was undertaken on nine lifeline utility networks following steps shown in Figure 2, for two main cases:

1. Base Case: the networks with existing vulnerabilities exposed to a major natural hazard scenario.

2. Improved Resilience Case: within the created model, specific investments are made to improve the resilience of the networks, and the upgraded networks are exposed to the same natural hazard scenario as in the base case.
Investigating sensitivity of results to uncertainties (if each explicitly modelled) in each case above would be interesting; this was, however, not considered significant for this project as the main aim was to demonstrate the relative impact.

As shown in Figure 2, the modelling workflow consists of three main components:

- Physical damage modelling - to understand the severity and extent of potential physical damage to the assets exposed to a hazard.

- Service outage modelling - to understand for how long the services will be lost (or operate at reduced levels of service) before the damaged assets can be repaired or alternate arrangements made to restore the services to the customers.

- Economic impact modelling - to understand the impact of service outages on regional and national economies at various times following the hazard event.

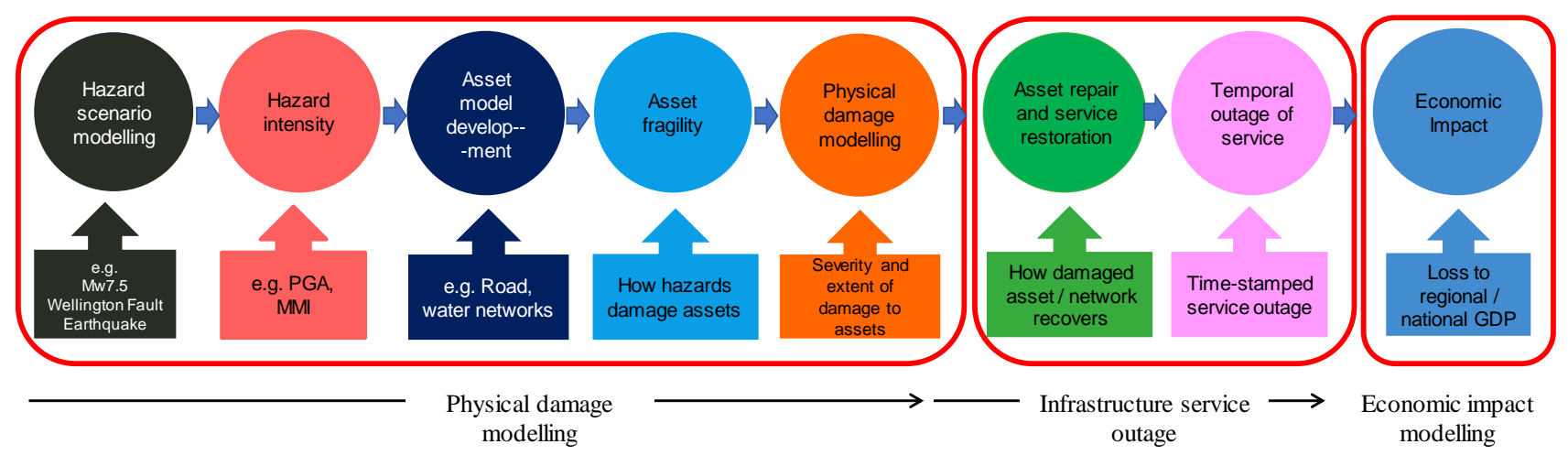

Figure 2: Impact modelling workflow. 
The focus of this paper will be on the first two modelling components, the results of which demonstrate the benefit of proposed resilience investments in reducing damage to the lifeline utilities and the resulting impact on services that they collectively provide to the Wellington region. The 'timestamped' service outage maps (i.e. for various elapsed times following the earthquake, such as two weeks, three months etc.) generated from this work were a key input to the economic impact modelling component, and they have been used to estimate the reduction in economic loss to the Wellington region (and the country) if the proposed infrastructure projects are implemented before the next major disaster. Details on the economic modelling are out of scope of this paper and can be found in the business case [9].

It should be noted that the scope of work expected readily available models to be used for damage and outage modelling, with any modifications to suit project requirements allowed in consultation with the stakeholders. Leverage on any relevant works done in the past, and a degree of engineering judgment, was also required while carrying out the assessments.

\section{HAZARD SCENARIO}

The choice of hazard scenario for this project was given careful consideration. To demonstrate the effectiveness of the PBC the hazard scenario had to be a major event that would cause widespread impact but still offers a credible recovery. Potential scenarios were discussed with all the participating lifeline organisations before selecting a $\mathrm{M}_{\mathrm{w}} 7.5$ Wellington Fault earthquake scenario for the impact modelling. This choice was underpinned by many reasons: (a) it is well-researched and commonly used for insurance risk assessments (e.g. [11]), business continuity planning etc; (b) it has a probability of occurrence of $\sim 10 \%$ in the next 100 years [12] (and therefore is a credible event), and is also a major contributor to significant hazard levels; (c) recovery of the region can be modelled following this major event; (d) it has many similar characteristics to other potential large earthquakes from other sources in the region (e.g. Ohariu Fault to the west of Wellington); so, intervention measures to mitigate the impacts from a Wellington Fault earthquake could also be effective against similar large earthquakes from other sources in the region; and (e) the benefits from proposed interventions should also minimise the impact from higher frequency but lower impact earthquakes in the region (and potentially also from other hazards such as flooding etc., dependant on the investment programme), or larger events that may occur at farther distances from Wellington (e.g. an Alpine Fault earthquake).
The following hazards relating to the Wellington Fault earthquake were included in the modelling: (a) ground shaking; (b) ground-surface fault rupture; (c) co-seismic subsidence caused by fault movement; (d) landslides; and (e) liquefaction and lateral spreading. A summary of the hazard datasets used for the modelling is given in Table 1 .

Spatial data of each of the networks analysed was acquired from the respective lifeline organisations and participating councils. It was then spatially overlaid on the ground motion map generated (Figure 3) to obtain the shaking level estimate at each asset location. For point assets (e.g. substations, fuel terminal site), the centroid of the asset footprint was considered to represent their location. Linear assets (e.g. pipes) were typically segmented into approximately $50 \mathrm{~m}$ lengths or shorter, and the centroid of the segment was taken to represent its location. Similarly, the asset layers were also overlaid on the other geological hazard maps (e.g. liquefaction susceptibility map) to enable each asset to be related to each potential geological hazard feature.

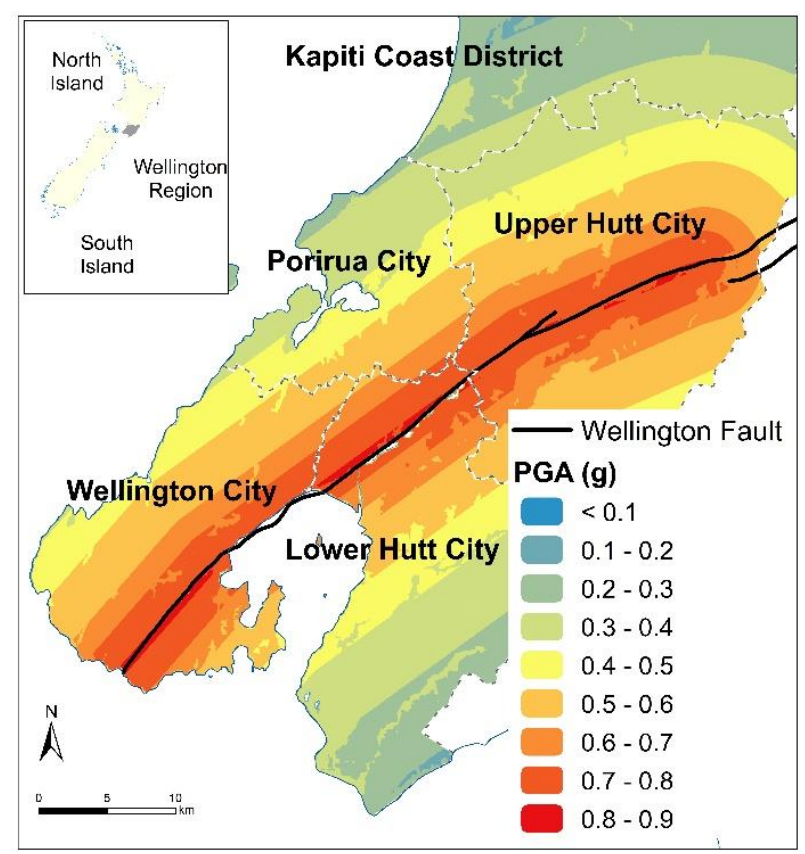

Figure 3: Modelled peak ground accelerations from the Wellington Fault earthquake scenario.

Table 1: Hazards considered for impact modelling.

Hazard

Fault rupture

Ground shaking from earthquake

Liquefaction and lateral spreading

Landslides from ground shaking

Co-seismic subsidence caused by fault movement

\section{Description}

Fault rupture is defined as a deformation zone around the fault trace. The mapped trace of the Wellington-Hutt Valley segment of the Wellington Fault (e.g. [13], [14]) was used, including a buffer for both expected ground deformation around the fault trace and for uncertainty of location.

The fault source model of the Wellington-Hutt Valley Fault (as defined in the NZ National Seismic Hazard Model [15]) was used and ground shaking across the region was estimated using the ground motion prediction equation of Bradley [16].

The latest liquefaction susceptibility map of the Wellington region [17] was used (Figure 4). Here, liquefaction susceptibility is a five-class dataset with values of none/negligible, low, moderate, high, and very high. A map of Liquefaction Severity Number (LSN) [18] was also used where the fragility models required this input.

Slopes in the study area have been mapped and assigned a probability of failure (and size of failure) given a level of PGA. These are then modelled stochastically based on the input PGA map (Figure 3). Realisations of landslide distributions were modelled using Road Risk Evaluation Tool [19].

Subsidence is defined here as the estimated mean subsidence of land caused by the rupture of the Wellington-Hutt Valley segment. Subsidence caused by fault movements can result in some areas being inundated by seawater. The model used for this project is based on work that is derived from a range of geological datasets [20] and only includes the Hutt Valley (Figure 4) as there has been little work to date on possible subsidence in other parts of Wellington from a Wellington Fault earthquake. 


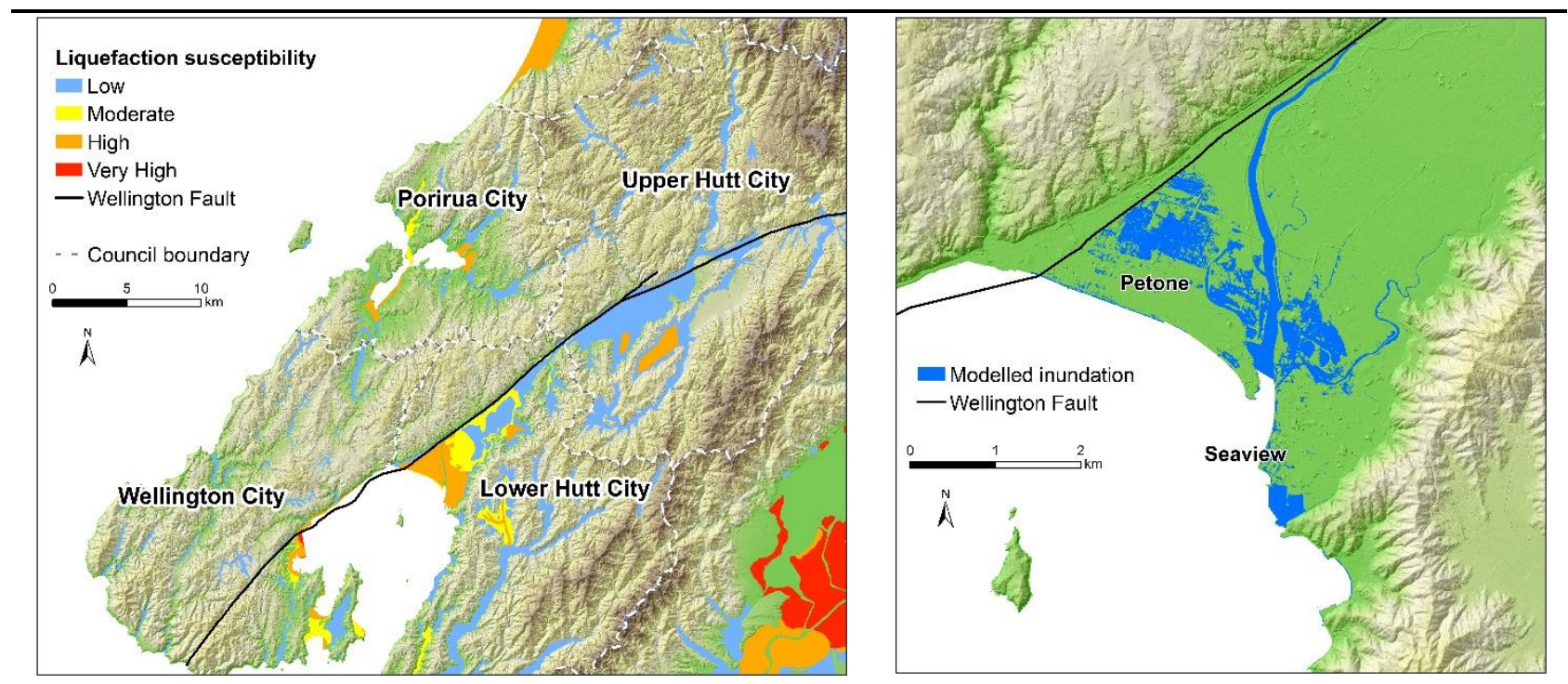

Figure 4: On left: liquefaction susceptibility of sediments in Wellington and surrounding cities. On right: Estimated extent of inundation (blue) from subsidence (areas below MSL) resulting from a Mw 7.5 Wellington Fault earthquake.

\section{PREFERRED INVESTMENT PROGRAMME}

A brief overview of the WeLG PBC is provided below; the full document can be found in [9].

The purpose of developing a $\mathrm{PBC}$ was to use a disciplined analytical approach to develop an integrated programme of infrastructure projects across the lifeline sectors that would improve the resilience of the region. The New Zealand Treasury's Better Business Case process was used to guide the development of the $\mathrm{PBC}$ which is being undertaken in stages: Stage 1: Demonstration of Benefits of Programme (completed in April 2018). Stage 2: Financing and Timing (completed in September 2019). The remaining Commercial and Management cases, which are also a part of the Better Business Case process, will be developed individually by the lifeline organisations in the future.

As part of the PBC, a series of workshops were held with all the participating lifeline organisations (17 in total) and government representatives to collectively identify problems to be addressed, discuss the potential benefits that could be gained by improving infrastructure resilience, and to define investment objectives. At every stage of the project due consideration was given to the importance of infrastructure interdependencies and to ensure any investment was focussed on delivering the best results for building the resilience for the region and not necessarily just for each individual utility. A 'long list' of over 140 resilience improvement options (covering all the lifelines in the scope) were initially put forward, which were after critical assessment short-listed and grouped into two programmes (lower and higher investment level programmes). A further assessment was made, and the two investment programmes were refined to one preferred programme. So, in total, three sets of modelling were undertaken to evaluate the economic benefit that the investment programme offered over the base case. We focus in this paper on the modelling work for the base case and the improved resilience case corresponding to the preferred investment programme.

The preferred programme comprises a total of twenty-five interdependent projects with a total initial capital cost of NZ\$3.9 billion (estimated in 2019). It includes projects across the fuel, transport, electricity, telecommunications, water and gas sectors (see Table A1 and Figure A1 in Appendix). Most of the projects are already in long term plans, have funding allocated and will bring substantial benefits under business-asusual assessments (such as safety or traffic flow improvements), while other projects are at an earlier stage of planning and will need further refinement; so, the costing shown in Table A1 should be treated as indicative.

The modelling assumes all the proposed projects will be completed before the next major earthquake. The projects have been sequenced (based on set principles, see [9]) to be delivered in three phases over a twenty-year period as shown in Table A1. Fuel, road, and electricity projects were found to provide the greatest interdependence and resilience benefits to other projects, so they were scheduled early in the 20 -year period. Projects with fewer dependencies were scheduled to be delivered later in the programme. We focus on the above three utilities in this paper. Modelling of the other six networks (water, waste water, telecommunications, gas, port and rail) followed the same workflow as explained in this paper; more details on the work carried on those networks can be found elsewhere [9,21-22].

It should be noted that all modelling was carried out on the assets and operations as were in place at the time of modelling. Since then there have been a number of projects carried out that improve the resilience of assets and improve operations to mitigate some impacts of a major earthquake. These are not listed here but are acknowledged to make a difference between modelled outputs noted in this paper and the current (2021) situation.

\section{ROAD NETWORK}

The road network within the study area was simplified into 24 transportation zones (Figure 5) and the routes chosen for modelling were based on pre-existing road hierarchies. This included all national, high volume and regional roads in the study area, as well as some arterial and collector roads. The geospatial data relating to the routes were sourced from Waka Kotahi - New Zealand Transport Agency (NZTA) for the State Highway network and from the five local councils for the local roads.

Past and recent earthquakes have shown that bridges, tunnels and retaining walls are generally vulnerable to ground shaking while significant damage to the road is also caused due to ground failure (e.g. liquefaction, surface fault rupture, landslide under cutting). Therefore, all the above assets along the routes were included for damage modelling. The geographic locations of the various structures along the road routes, and the corresponding asset data / attributes defining the structures (e.g. type, age, construction material, structural configuration), were all stored in GIS layers provided by the road authorities. The 
continuous line segments representing the routes were then discretized into segments and spatially overlaid on the hazard maps to enable each road segment to be related to the potential geological hazard features at its location. The analysis of the road network was broken down into two 'levels of service' for 'response' and 'recovery' (details below).

Note that where there were any gaps in the asset data provided, additional information / proxy attributes were sought from the

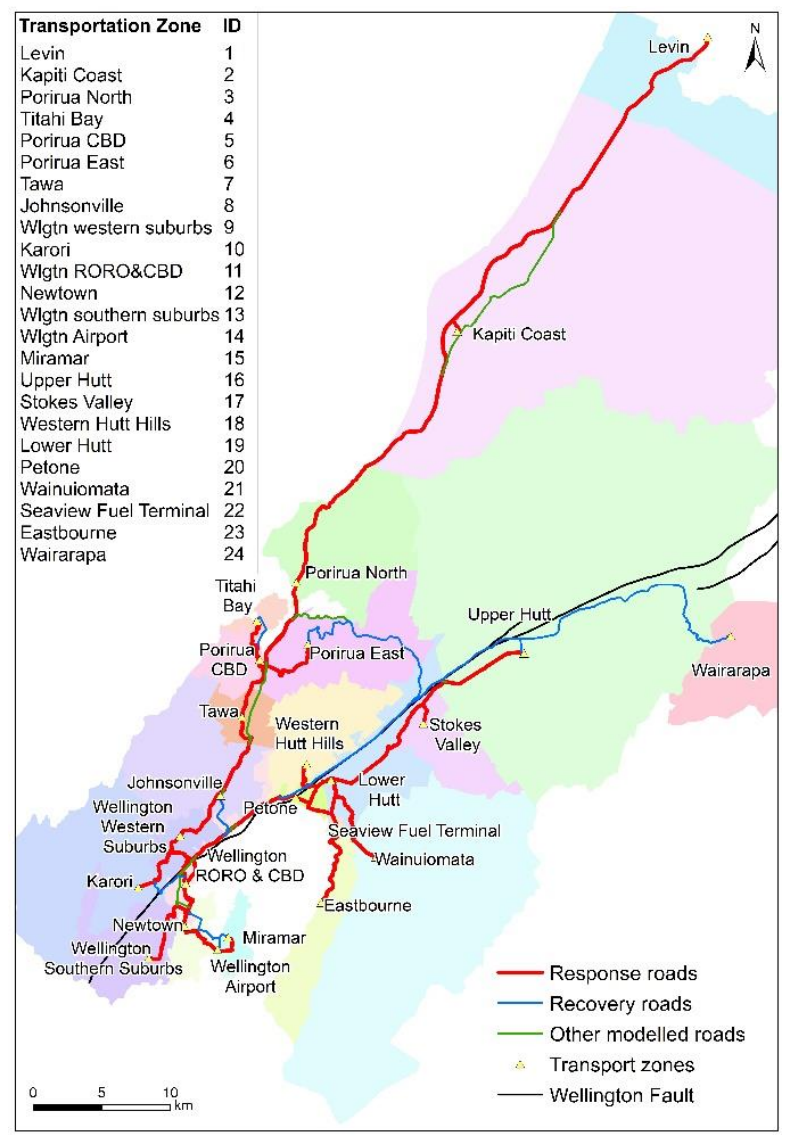

Figure 5: Road zones and roads modelled in this study. roading teams. A degree of engineering judgement was also required to be applied when there was no/insufficient asset data available for modelling purposes or to qualitatively assess the potential damage under the chosen scenario. Also, information gathered (e.g. seismic assessment results for bridges) for a previous study [23] was useful for this project.

\section{Base Case}

Under this case the earthquake is assumed to strike the assets in their current "as-is" state. For fault rupture and subsidence hazards, a critical (i.e. complete loss) damage state was assigned to each asset if it is within or intersecting the hazard footprint area, otherwise a 'no damage' state was assigned. Damage state assignments for the other perils depended on the vulnerability of the asset (guided by the asset attributes/characteristics) and the hazard parameter at its location: (a) estimated ground shaking level and liquefaction/lateral spreading potential; (b) volume and spread of debris from modelled landslide distribution.

Damage to one or more assets can result in disruption to the normal traffic flow (i.e. pre-earthquake condition) at any road segment. The damage state of each asset resulting from the modelling was translated to Service Disruption Levels (SDL) [19] of traffic flow from their unimpeded capacity. These levels range from SDL0 (no disruption) to SDL4 (complete closure); the intermediate levels represent either partial closure or imposition of various levels of restriction - e.g. speed restrictions, single lane flow or possible limits on vehicle weights etc. Figure 6 shows a single actualisation of the basecase road service disruption map for the chosen earthquake scenario. Many runs of the model will bring many different actualisations, with the one used in this study considered most representative of the model outputs, even if this brought results that were surprising or less intuitive in some specific locations. The map shows the critical SDL for each road segment from all assets exposed to all perils considered - i.e. for example, consider a road segment with a bridge and a tunnel; if the assessed SDL due to bridge damage $=3$, SDL due to tunnel damage is 2, and the SDL from damage to road itself is 4, then the governing SDL (= 4 in this example) is assigned to the road segment.

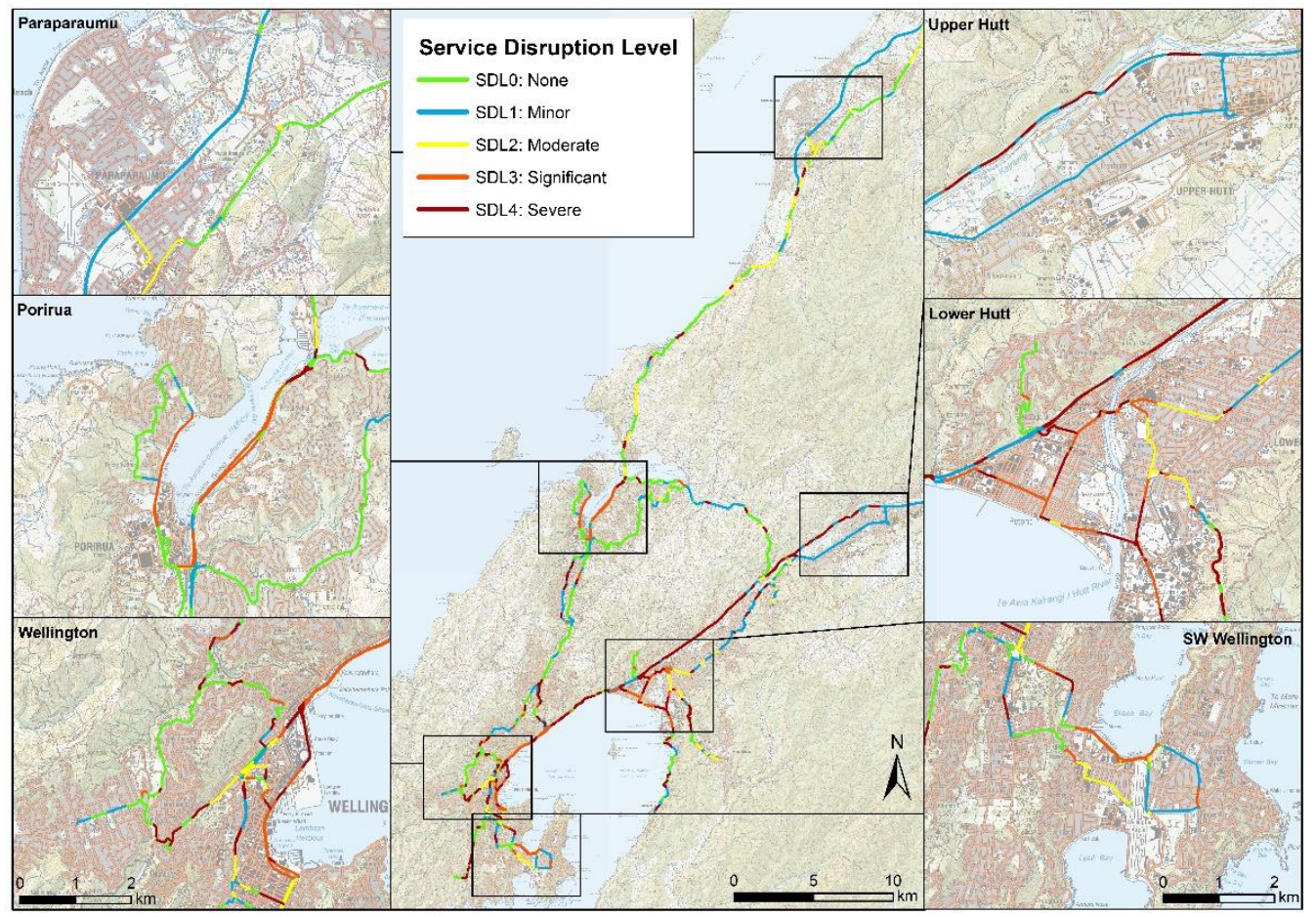

Figure 6: Potential road service disruption (Base Case) under the Wellington Fault earthquake scenario. 
The output from damage modelling was reviewed by the respective roading teams during consultation on service restoration times. The two levels of service considered for roads were: (a) response (i.e. access for vehicles such as a 7.5T twoaxle van used for emergency purposes during the initial days following the earthquake); and (b) recovery (i.e. access for all vehicles). Where it was required to assist in estimating the times for providing access between the transportation zones, results from an earlier study [24] were also discussed and applied by the roading teams. Repair strategies/sequences were explored considering network operation hierarchy, inter and intra dependencies of the network components, priority/critical customer needs, availability of repair equipment/machines, replacement materials etc. A number of assumptions were made when estimating the road outage times; the key assumptions included that:

- there will be minimal debris on the road from failed buildings/structures in residential areas;

- potential road closures due to (post-earthquake) precarious buildings is not considered in this analysis;

- Urban Search and Rescue (USAR) Taskforce needs may have a higher priority for earthmoving equipment, which may extend road re-opening times;

- response and recovery roads could all be used in the restoration of traffic;

- repair equipment/machines, replacement materials, fuel etc. are all available for road-reopening activities; and

- staff/repair crews will be available (sourced from within or outside the region) to work on road-re-opening activities from day 2 following the earthquake.

The estimated base-case restoration times for road access between the transportation zones for the two levels of service is shown in Table 2.

Note that this study assumed that the construction of Transmission Gully Motorway would be complete by the time that the results of this study were to be used. This impacts the modelled outages between the Kapiti Coast and the areas to the south of it, due to the level of resilience being designed into the new road.

As highlighted earlier, a key feature of the PBC was to understand interdependencies between lifelines and incorporate or make allowance for them in the modelling. Road access is typically required to reach sites to undertake repairs on damaged assets in other networks. Therefore, the estimated road restoration times were a key input when calculating service outage times of other networks (e.g. water and wastewater). The dependency of road access to restore fuel and electricity services will be shown later in this paper.

\section{Improved Resilience Case}

In this case the same earthquake scenario was assumed to strike the same network, but with specific infrastructure investments made, such as new roads constructed, or strengthened structures along the roads. Eight roading projects feature in the preferred investment programme; the project details and the significance of each are given in Table 3. An example of the benefit that can be achieved by implementing the proposed projects is shown in Figure 7. It shows how the roading initiatives (shown by dotted blue lines) will improve the access route between two example locations - the Seaview fuel terminal and the Wellington CBD. Should the roads between Petone and Ngauranga become inaccessible (shown by the red $\mathrm{X}$ ), the alternate routes formed due to the combined efforts of the roading improvements will likely help reduce the service disruption.

For the improved resilience case, due to the nature of the proposed intervention projects it was decided after consultation with the respective roading teams that no explicit damage modelling of these projects was necessary. It was assumed that the proposed works would undergo detailed engineering assessments, geotechnical investigations, and would meet current standard requirements etc., and risks identified would be addressed accordingly prior to construction. The effect of the proposed roading projects in reducing damage to the improved network was therefore qualitatively assessed and, in consultation with the roading teams, the restoration times were estimated for the two levels of service (Table 4).
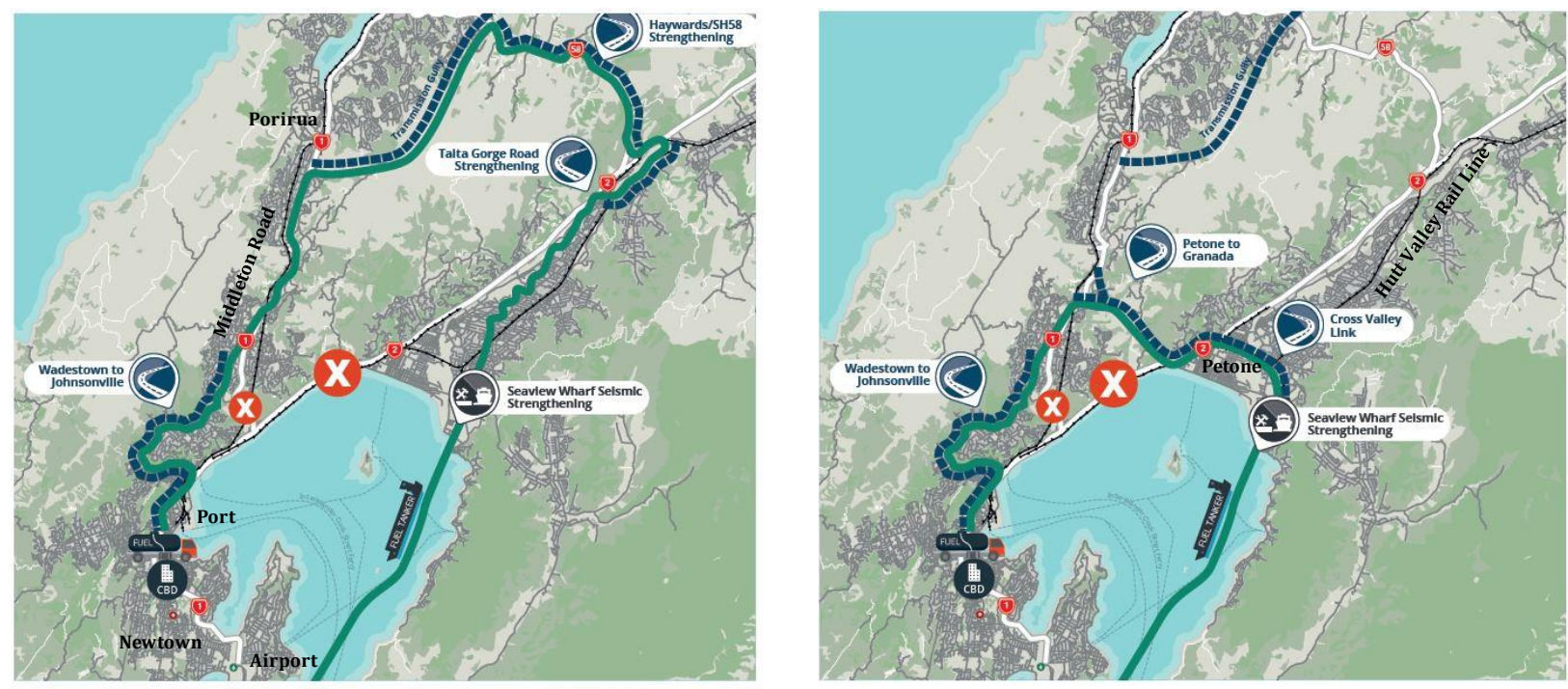

Figure 7: Examples of proposed roading initiatives (shown by dotted blue lines) to improve regional resilience and their resulting improvement in route choice (green line) between two example locations (Seaview and Wellington CBD). The main fuel distribution point for the region is through Seaview Wharf and the tank farms at this location. Original map credit: Aurecon. 


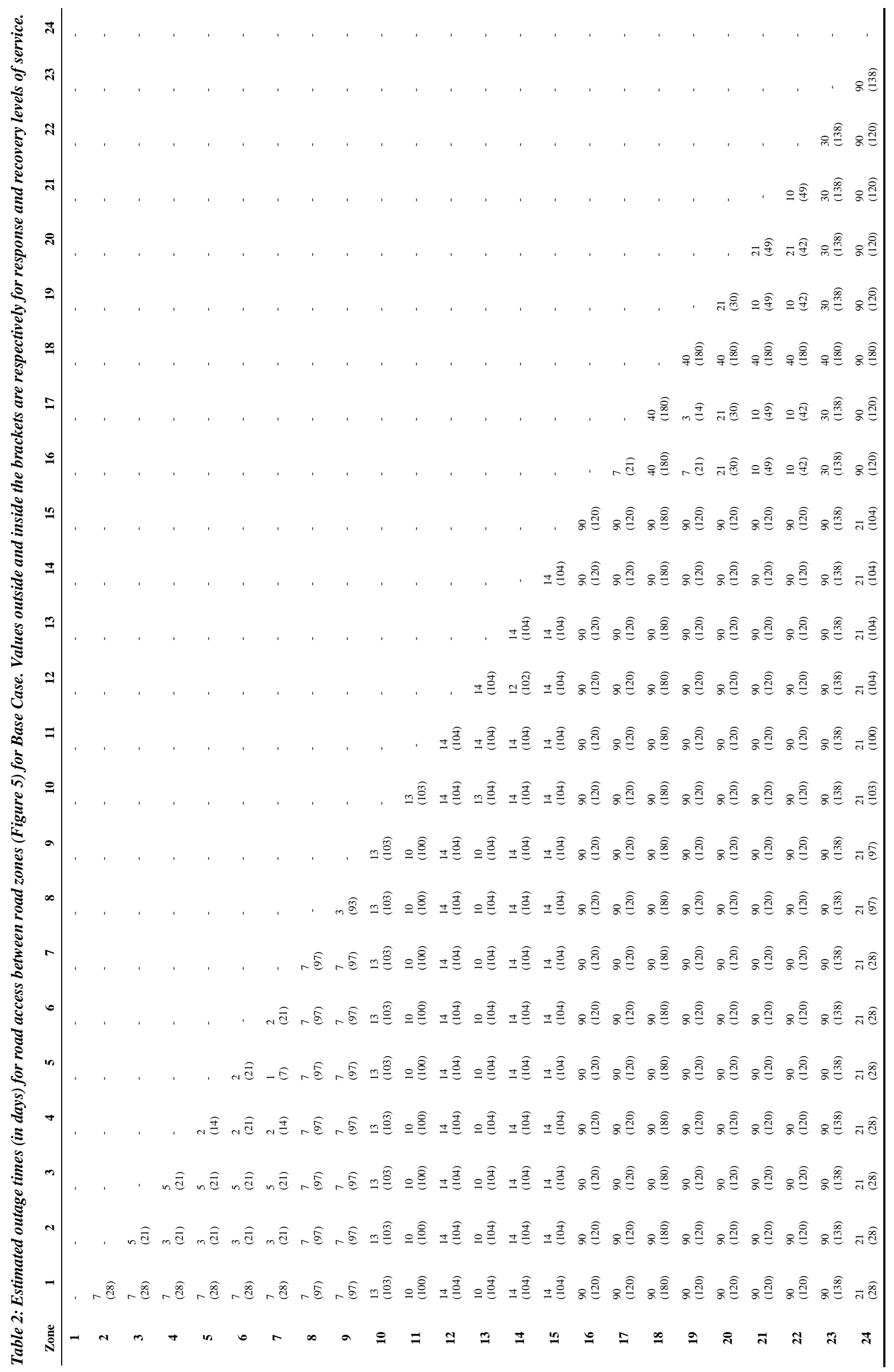


Table 3: Proposed roading projects in the Preferred Investment Programme [9]. All cost estimates are in NZD.

Project

SH58/Haywards Resilience

Improvements from Transmission

Gully to Hutt Valley

Phase 1: 0-7 years

Cost est. (2019): \$24m

Taita Gorge Access -

strengthening road network

Phase 1: 0-7 years

Cost est. (2019): $\$ 2.5 \mathrm{~m}$

Wadestown to Johnsonville seismic strengthening

Phase 1: 0-7 years

Cost est. (2019): $\$ 20 \mathrm{~m}$

Improve resilience of airport connectivity to city network via

Newtown

Phase 1: 0-7 years

Cost est. (2019): $\$ 10 \mathrm{~m}$

Better engineered road links to existing roll-on-roll-off (RORO)

Terminal and port area

Phase 1: 0-7 years

Cost est.: $\$ 71 \mathrm{~m}$

New road: Petone to Grenada

Phase 2: 8-14 years

Cost est.: Capital cost: $\$ 250$ million to $\$ 2,200$ million (2018 re-evaluation summary report), however for the WeLG PBC report the figure of $\$ 1,062$ million was used.

Cross Valley Link (new road) $\mathrm{SH} 2$ to Seaview

Phase 2: 8-14 years

Cost est. (2019): $\$ 65 \mathrm{~m}$

Middleton Road retaining walls upgrade

Phase 3: 15-20 years

Cost est. (2019): $\$ 50 \mathrm{~m}$
Proposed Work and Significance

This project includes stabilisation of slopes above SH58 at Haywards Hill from SH2 to summit.

This project will provide alternate access through to Porirua from the Hutt Valley. This will allow residents of the Hutt Valley to travel through to Wellington City via Porirua (and vice versa) in the likely event that access along the SH2 coastal road (depicted by larger X in Figure 7) is cut off. This project will also provide access for fuel trucks to transport fuel from Petone through the region. The safety improvements element of this project has been committed.

This project will involve stabilising slopes and upgrading the walls supporting the Eastern Hutt road.

This project will help prevent collapse of the Eastern Hutt Road into the Hutt River, maintaining access up the eastern side of Taita Gorge following an event. This project also helps maintain access to Hutt Hospital.

This project involves strengthening the retaining walls and engineering of some major uphill slopes on Churchill Drive, Blackbridge Road and Wadestown Road, which service Bowen Hospital.

This route is likely to be one of the first access routes open for ambulances to get through to Bowen Hospital. This route also provides access through to critical Wilton Substation for inspection and repair following an event and provides a potentially important secondary route towards Wellington's CBD.

This project involves emergency response planning for the roads alongside the Hospital. It would also involve potential interventions around the Mt Victoria Tunnel portals to protect from landslides either side and reduce the tunnel outage time.

This project provides access from Wellington Airport through to the CBD should the Evans Bay route be blocked due to landslides. This provides access through to the airport for personnel, for both the response and recovery periods.

This project involves mitigation measures to potential liquefaction on Aotea Quay following a seismic event, seismic upgrading of the Skew Rail Bridge and an emergency ramp from SH1 to the roll-on roll-off (RORO) area at the port.

The project would enhance the likelihood of access both to the core port and to a RORO facility.

This project includes a new road link from Hutt Valley to SH1. It will include slope stabilisation measures and basic resilience enhancements to increase the chance of a link between the two corridors following a 7.5 Wellington Fault earthquake event. A more resilient version with a very low probability of closure would be possible at a significantly higher cost.

This project was re-evaluated by the Transport Agency in 2018. The re-evaluation recommended the project be redesigned with a focus on resilience, safety and improving transport choice across the state highway network. The next step is to seek funding for the development of a business case, which will include working with the community and local government partners.

This option provides significant benefits to communities in terms of access into and out of the Hutt Valley. It also improves the lifeline restoration times of other lifelines which require road access to refuel and repair.

The Cross-Valley Link proposal (also known as East West Connection) currently has provision of a new grade separated two-lane road with cycle lanes between Hutt Road in the west and White Lines Road in the east, approximately following the alignment of the Hutt Valley Rail Line. The project would be constructed to withstand probable liquefaction and bridges or raised piers would be constructed to ensure the route is useable following an earthquake event.

From a resilience perspective - given the criticality of fuel to the recovery of the Wellington Region following a major event - this link would provide a stronger connection between the fuel terminals at Seaview with the transport network and the rest of the region.

This project involves the strengthening of retaining walls for gas main protection. Minor improvements to batter slopes may also be included to reduce the amount of material likely to slide during an event, and therefore reduce the recovery time.

By strengthening the existing retaining walls there will be fewer and smaller landslides along Middleton Road from an earthquake event, therefore improving the recovery time for the gas main which is currently located beneath Middleton Road. This project also provides an alternate route through Johnsonville should there be damage closing SH1.

Note: Funding/scope for the NZTA projects are indicative only and full assessment/investigation/design may change the extent/cost of the initiative(s). 


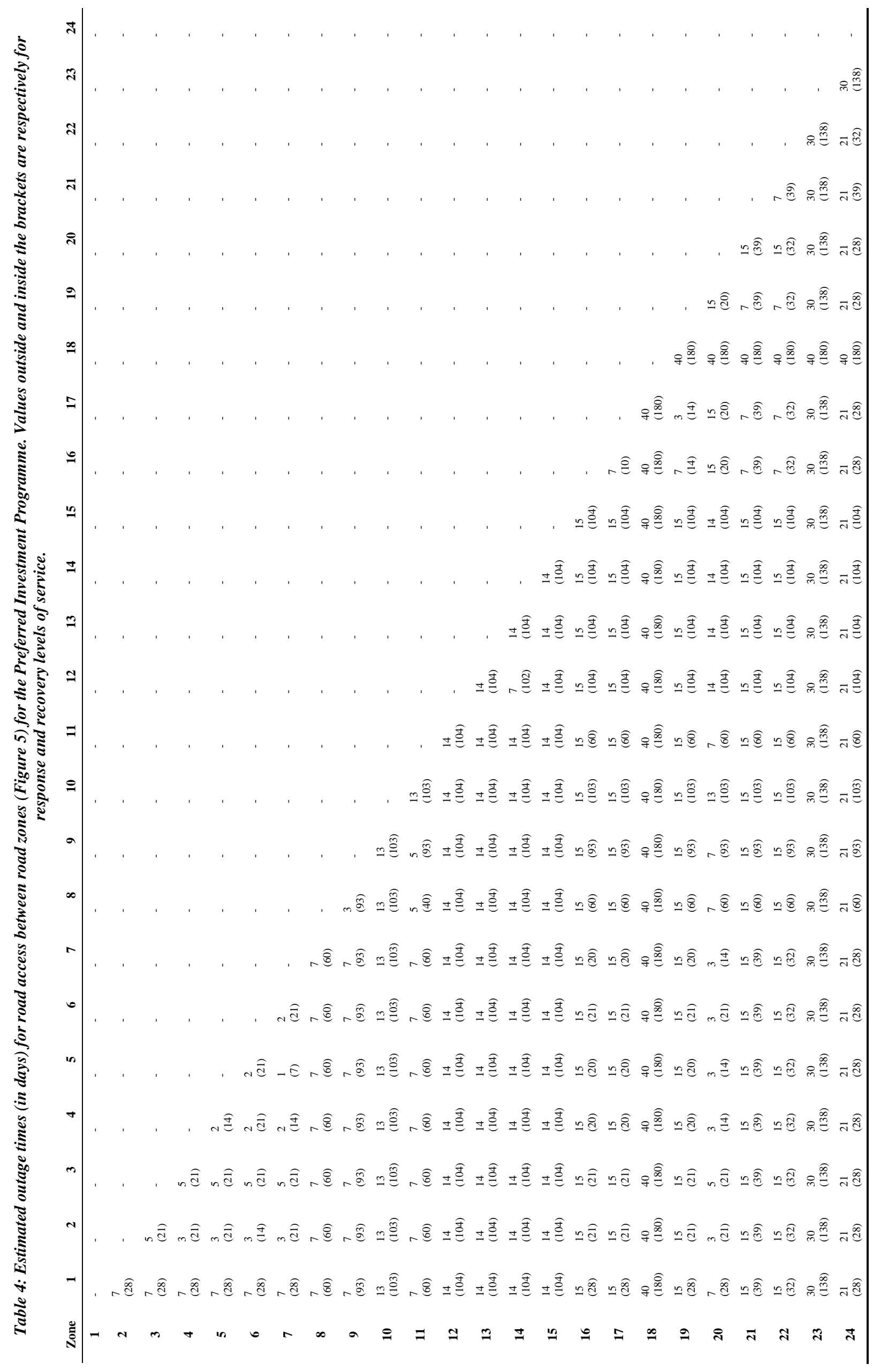


FUEL

Similar to many regions in New Zealand, fuel supply to the Wellington region is from both a New Zealand source and directly imported from overseas. There are three entry / distribution points in the study area for fuel supply to the region (site locations in below order shown in inset in Figure 8):

1. Seaview - Diesel, petrol and other fuel at the Seaview depots are transported to the customers around the region and to the lower North Island by road tankers.

2. Aotea Quay - Marine diesel and fuel oil delivered to this location is used to refuel ferries and ships that berth at this location.

3. Miramar-fuel imported via Burnham wharf is used to meet the airport's fuel demand.

The potential damage to assets and the resulting impact on port and airport operations under the chosen earthquake scenario was assessed separately. To understand the impact on fuel disruption to the majority of the region's population and business fuel demands, only the Seaview facility was focussed on in this project.

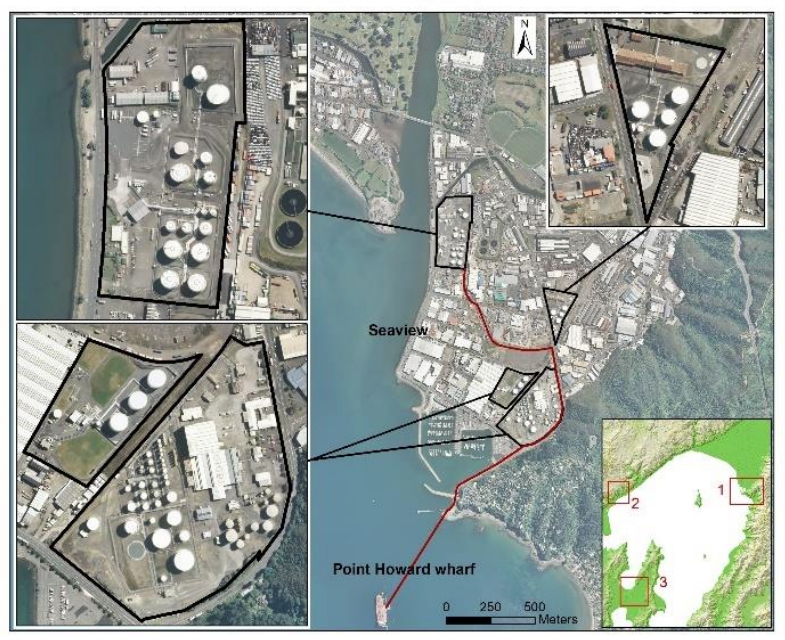

Figure 8: Seaview fuel storage facilities, with the location of all facilities in Wellington shown in inset. The fuel lines to the Seaview tank sites are shown in red.

The fuel supply to customers can be disrupted due to damage to: (a) intake infrastructure such as berthing structure, wharf and pipelines; (b) storage tanks and other components (e.g. pumps); (c) service stations; and (d) the roads used to transport fuel from the storage facility to the service stations.

For this study the assessment was carried at a high-level in the following way. First, the expected seismic performance of the berthing structure, wharf and supported pipes, and the storage tanks was assessed utilising the information on the modelled hazards and the vulnerabilities of the assets exposed to each. Service stations were not explicitly modelled. Literature on performance of similar assets (i.e. similar to the ones in the assessed portfolio) in historical earthquakes, gathered for a previous study [25], was also referred to for the damage assessment. Then, the repair times to fix the potential damages was estimated in consultation with the companies associated with the port facilities. Finally, the effect of the disruption to road access to transport fuel to different suburbs was accounted for in estimating the final outage time for fuel supply to critical and non-critical customers in each road zone (see Figure 5).

When deriving the fuel outage times, it was assumed that:

- there will be enough standby facilities at the terminal sites for electricity supply required for their continued operation;
- alternate source from a fuel depot elsewhere in the North Island will be possible;

- at least some service stations in each zone will be functional (i.e. not all service stations will be badly damaged or inoperable);

- some means of standby power supply facilities will be available at the service stations, if required;

- critical customers will get priority over others (i.e. general population) to receive fuel until services are fully restored; and

- service stations in each road zone will collectively have fuel to last for at least five days following the earthquake to serve the critical customers in the respective road zone.

\section{Base Case}

Under the earthquake scenario considered the tanks were assessed to be sufficiently robust to retain product and assumed to have collectively stored enough fuel before the earthquake and could meet critical customer's needs for at least six weeks following the event. Once the Seaview Wharf and the fuel lines to the tank sites are repaired and fuel intake restored (assumed possible within the above six-week period), the fuel storage at the Seaview sites can be expected to increase to pre-earthquake levels so could cater to the fuel needs of the general population from week seven onwards. In all cases the stored fuel can be transported from Seaview (or an alternate source) to different suburbs only when road access is re-established.

Time-stamped outage times were calculated for each road zone and customer type. As mentioned earlier, service stations in each zone are assumed to collectively have residual fuel that will last for up to five days following the earthquake. The stored fuel is assumed to be supplied to only critical customers in the respective road zone. From day six onwards, the fuel supply from the Seaview terminal to the critical customers can resume only after the roads to the zones become available. As can be seen from the response road outage times in Table 2, timeframes to reconnect Seaview road zone (ID: 22) and the western suburbs from Levin to Wellington Airport and Miramar (ID: 1 to 15), also to the Wairarapa (ID: 24), are longer than between those suburbs and Levin (due to the relatively shorter road outage times from Levin). Fuel is therefore assumed to be supplied from alternative sources on the North Island to Levin. From there, further distribution to the above zones can happen when the connecting roads are re-established. Fuel supply to the critical customers in the other zones (ID: 16 to 23) will be from the Seaview terminal, and this supply (from day six onwards) can happen when the connecting roads are re-established.

Following the same assumption as explained above for the critical customers, supply for the non-critical customers (i.e. general population) in Zones 2 to 15 (and 24) can resume via. Levin as soon as the connecting response roads become available. It was assumed in this assessment that enough volume of fuel from the alternate source(s) will be available following the earthquake for both the customer types in these zones. For non-critical customers in the other zones (i.e. ID: 16 to 23), the fuel supply will be from the Seaview Terminal, and this service will commence from week seven onwards. This delay is due to the stored fuel at the Seaview facility reserved for critical customer needs for the first six weeks (time estimated to fix damage to the Seaview Wharf and the fuel lines to the tank sites).

The base-case restoration times estimated for fuel service (to pre-earthquake levels) to critical and general customers in the study area is shown in Figure 9. 

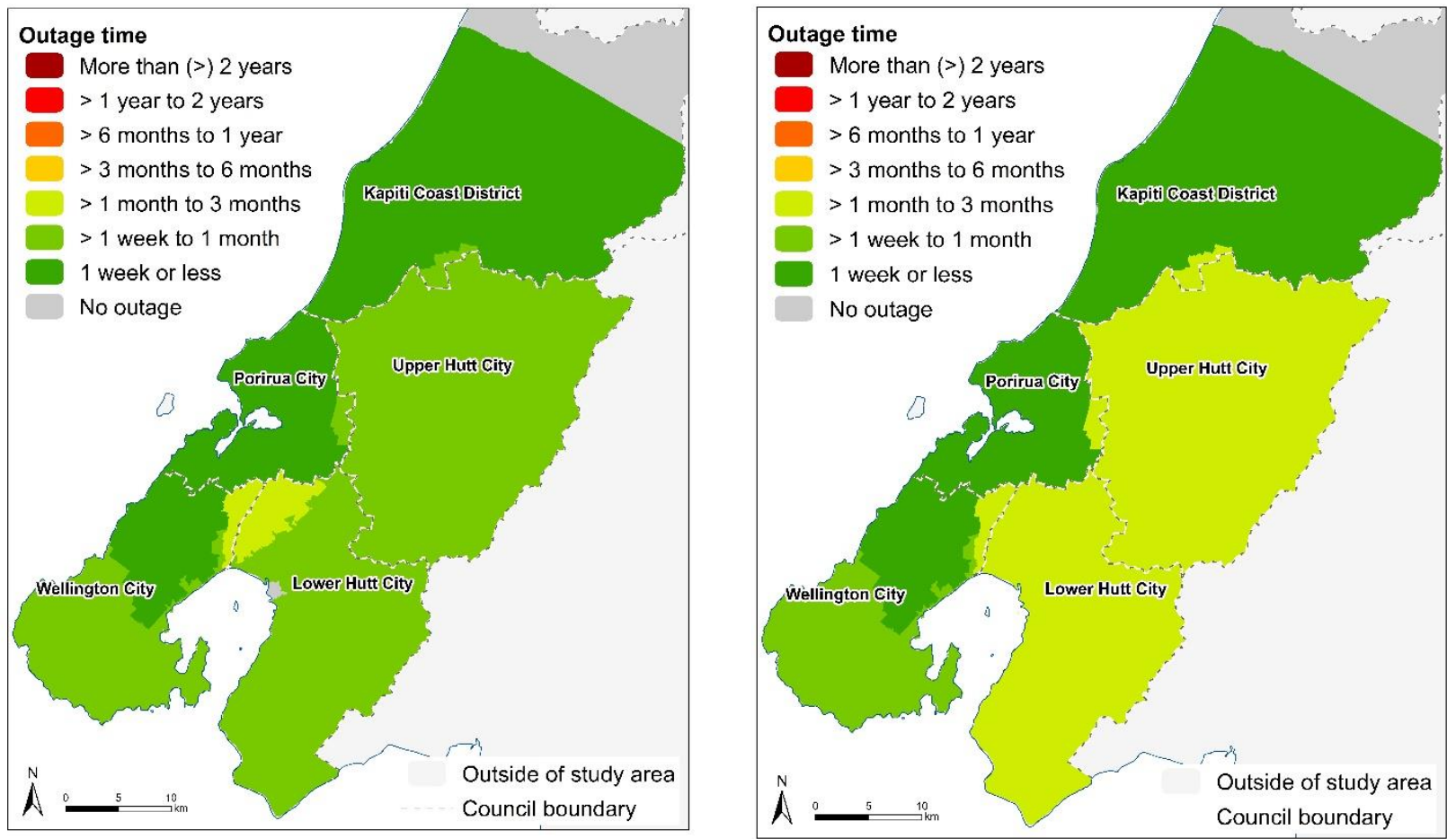

Figure 9: Estimated fuel service outage times for critical (left) and non-critical (i.e. general population) customers - Base Case.

\section{Improved Resilience Case}

Only one intervention project for the fuel sector was considered in the programme. This project involves strengthening the Seaview Wharf and the associated $3 \mathrm{~km}$ of fuel pipelines that extend from the end of the wharf to the furthest of the tank farms (see Figure 8). It will also include conversion of the pipeline to operate in both directions (currently only one direction) to enable both withdrawal and filling. This project will require the installation of a mooring dolphin to enable berthing in all weather conditions and take account of the likely ship sizes used for transporting fuel in the future. The proposed project has been scheduled to begin construction early in the first phase of the programme with a capital cost estimated (in 2019) to be NZ\$10 million for fuel infrastructure and another NZ $\$ 25$ million for the wharf improvements.

Under the same earthquake scenario as considered for the base case, the above strengthening work is assessed to maintain a continuous supply of fuel to the Seaview tank farms following the earthquake. Therefore, stored fuel at Seaview storage sites is expected to be available for both critical and general customers, provided there is road access from the storage sites here to the customers in the respective road zones. Recognising the critical need for fuel during response and recovery phases following the earthquake, supply via. Levin (as done for the base case) is assumed for all zones where road connectivity can be re-established in less time than from the Seaview Terminal. As done for the base case, supply from the alternate source(s) is assumed to be available for both the customer types. Note though that while fuel may become available sooner for the general customers, road access for them to reach the service stations may not be available due to long delays in restoring the roads for them in some zones (see recovery road outage times in Table 4).

The estimated restoration times for fuel service (postimprovements) to the critical and general customers in the study area is shown in Figure 10. The benefit of the proposed investment to improve the resiliency of the Seaview facility can be seen by comparing Figure 10 with Figure 9 (i.e. fuel outages are reduced with the upgraded facility).

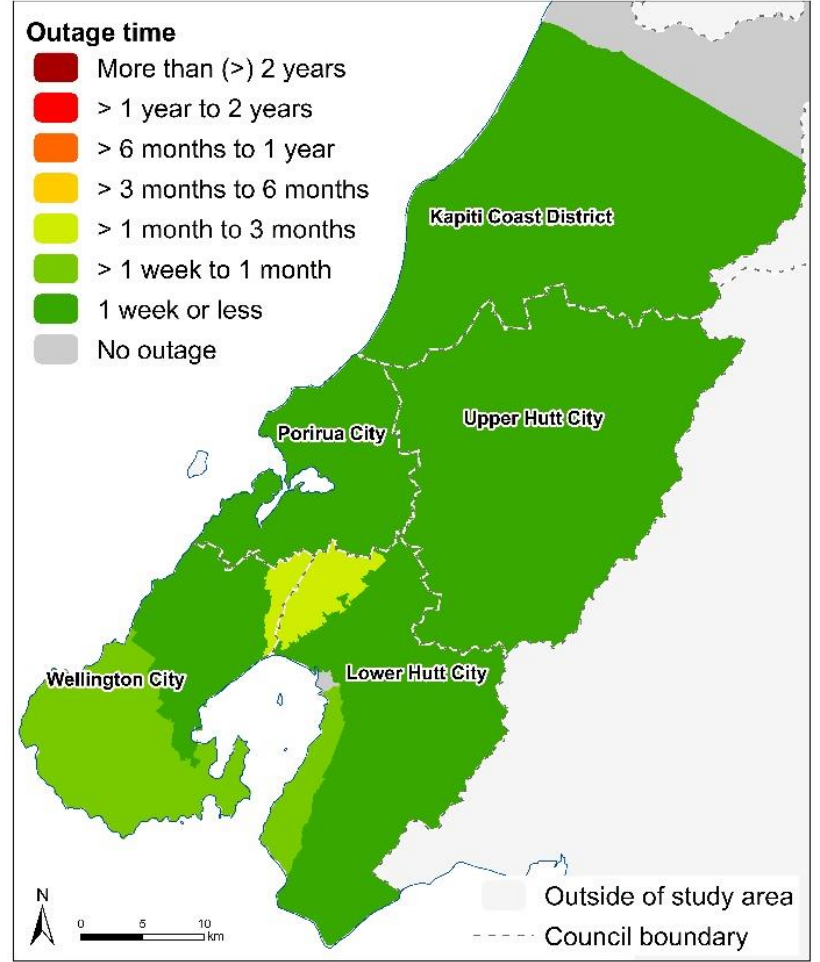

Figure 10: Estimated fuel service outage times for critical and non-critical customers - Improved Resilience Case.

\section{ELECTRICITY NETWORK}

The electricity network in the region includes the national grid network and the local distribution networks. Electricity enters Transpower's national transmission grid from North and South Island generation plants, as well as from regional wind farms, from where it is transported by overhead transmission lines. Electricity enters the local distribution networks through Grid Exit Point (GXP) substations (see Figure 11) and is distributed by buried cables and overhead lines to zone substations and local substations within the distribution network, which itself is made up of buried cables and overhead lines. Zone substations 
supply to specific coverage zones and are typically enclosed within a building whereas GXPs are typically partially enclosed within a building, or multiple buildings, with exterior plant equipment common.

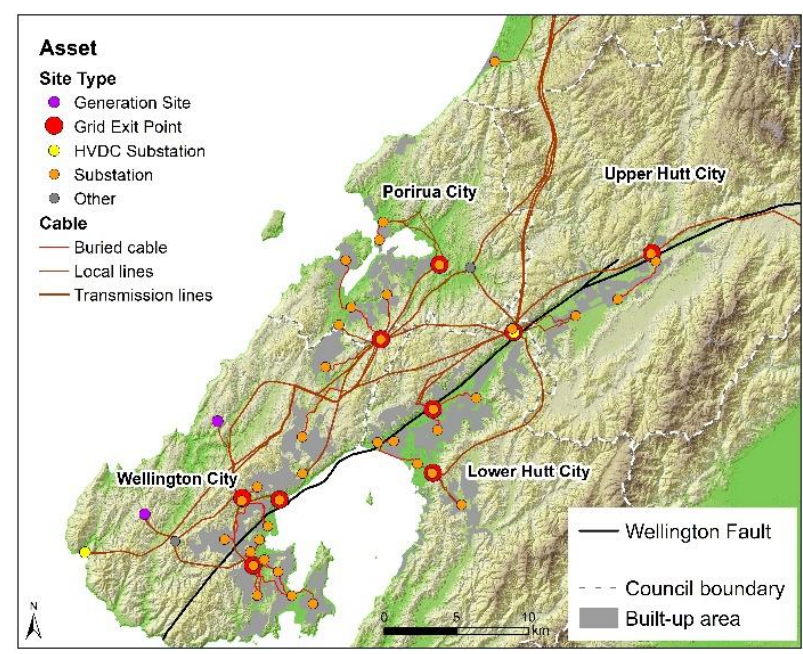

Figure 11: Electricity network assets in the study area.

Table 5 shows the assets considered and the key attributes that are required for selecting appropriate fragility models as per Table 6. Prior to the modelling, the selected fragility models were discussed with the stakeholders and any modifications required were made before assigning them to the assets.

\section{Table 5: Electricity network assets considered for impact modelling.}

\begin{tabular}{|c|c|}
\hline Asset Type & Key Asset Attributes \\
\hline $\begin{array}{l}\text { Transmission } \\
\text { Structure }\end{array}$ & $\begin{array}{l}\text { Location, structural type (e.g. steel lattice } \\
\text { tower, tubular steel single/double/triple } \\
\text { pole) }\end{array}$ \\
\hline $\begin{array}{l}\text { Grid Exit Point } \\
\text { (GXP) }\end{array}$ & $\begin{array}{l}\text { Location, voltage level, construction type, } \\
\text { age, condition }\end{array}$ \\
\hline $\begin{array}{l}\text { Terminal and Zone } \\
\text { Substations }\end{array}$ & $\begin{array}{l}\text { Location, voltage level, construction type, } \\
\text { age, seismic restraints }\end{array}$ \\
\hline $\begin{array}{l}\text { Overhead and } \\
\text { Buried cables/lines }\end{array}$ & $\begin{array}{l}\text { Location, length, voltage level, conducting } \\
\text { and insulating material, age }\end{array}$ \\
\hline
\end{tabular}

Assessment of damage state for all assets comprised the following steps. (a) A random weighted distribution was used based on the probability of reaching or exceeding each damage state. This was carried out using a single scenario realisation; (b) Based on the assigned damage state for ground shaking from the above approach and the exposure of the asset to potential liquefaction at its location, a liquefaction damage state enhancement was applied; (c) If the asset was exposed to coseismic subsidence or fault rupture or landslides, it was assumed that the asset would be severely damaged, so a critical damage state (i.e. complete loss) was assigned in such cases; and (d) The governing damage state (from all perils considered) was assigned to the asset.

\section{Base Case}

As done for the other networks, the damage modelling results from the preliminary assessment of the electricity network were presented to the network providers to verify any assumptions made. The analysis was then re-run (after incorporating any changes to the model) to produce the damage map shown in Figure 12.

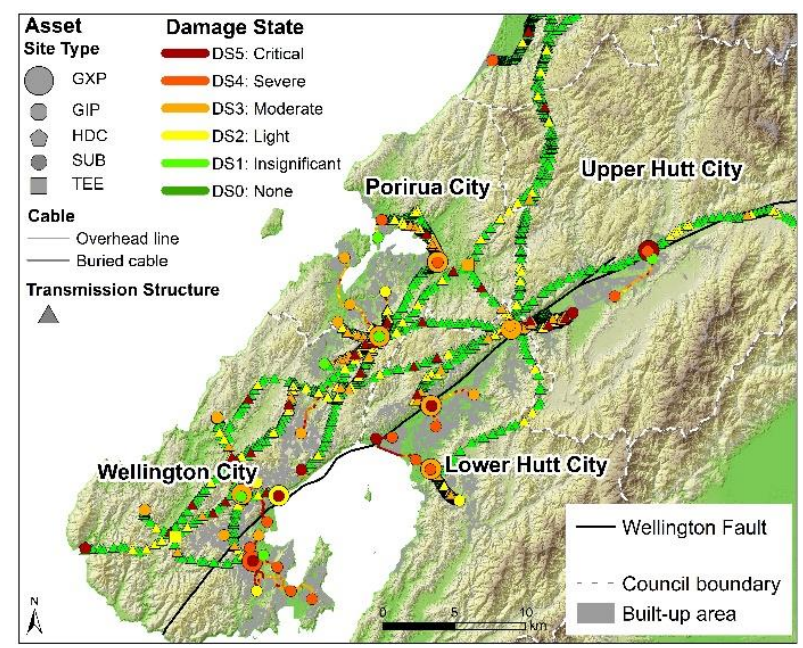

Figure 12: Potential damage to the electricity network (Base Case) under the Wellington Fault earthquake scenario.

The results in Figure 12 formed the key basis for estimating the service outage times. The following key assumptions were made in consultation with the network providers when deriving the repair/restoration time:

- Most of the necessary resource and associated equipment and material would be locally available within the region, and there would be repair crews to undertake restoration work in multiple locations at a time. Additional repair crews could be expected to be available after the initial response phase, which would speed up the recovery timelines.

- The estimated repair times and preferred strategies for various components were discussed and agreed with the network providers.

- Solid insulated cables (XLPE, PILCA, PVC and cables with type "Others") are assumed to take 3 days per fault (DS > DS3) to repair with possibility of two repairs simultaneously done on a circuit. These circuits will be abandoned if nine or more faults are on the circuit.

Table 6: Fragility models for electricity network assets.

\begin{tabular}{llll}
\cline { 2 - 3 } Asset Type & Ground Shaking & $\begin{array}{l}\text { Hazard } \\
\text { Liquefaction and } \\
\text { Lateral Spreading }\end{array}$ & $\begin{array}{l}\text { Other Perils (Fault Rupture, } \\
\text { Subsidence, Landslide) }\end{array}$ \\
\hline Transmission tower or pole* & $\begin{array}{l}\text { Xie et al. (2012) [27] } \\
\text { Terminal and Zone Substation }\end{array}$ & $\begin{array}{l}\text { Federal Emergency Management } \\
\text { Agency (2015) [28] }\end{array}$ & $\begin{array}{l}\text { King et al. (2017) [26] and } \\
\text { engineering judgement. } \\
\text { complete loss) damage state is } \\
\text { assigned if the asset is within } \\
\text { or intersecting the hazard } \\
\text { footprint area, otherwise a 'no } \\
\text { damage' state is assigned. }\end{array}$ \\
\hline
\end{tabular}

* Overhead lines are not directly modelled for damage, but instead use transmission structure damage as a proxy for their own damage state. That is, the highest damage state between either transmission structure is assigned to the linking cable. 
- Fluid-filled cables (PIAS) are complex and time-consuming to repair. The first repair on a cable will likely take 15 days to repair; the cable circuits will be abandoned if there is more than one cable fault on the circuit. There are limited skilled resources in NZ to fix these faults.

- Emergency overhead lines are planned to be installed for the circuits that will be abandoned. Their construction from source GXP to target zone substation is assumed to need 20 days, and four such circuits can be simultaneously installed. The first four circuits to be repaired will be determined based on top priority sites identified based on their functionality (e.g. hospitals, emergency management organisations, police headquarters). Additional resources (e.g. hardware and line staff) can be expected to become available by the end of 20 days (i.e. completion of the first four circuits installation), so all the remaining circuits are assumed will be built in the following 20 days.

Repair time estimates for the substations and transmission structures are according to Table 7.
Road access to the site locations will be required to repair or replace the damaged assets. The following steps (also see Figure 13) were taken to include the impact of the road outage on the recovery of electricity services to each zone substation coverage area:

1. Every electricity asset was spatially mapped to a road zone;

2. The restoration of a damaged asset can commence once the road access is re-established between the road zone where the asset is located and the road zone from where the repair resources will be provided. For all zone substation coverage areas, the Lower Hutt zone was defined as the source location for stocking the required replacement parts and equipment (as was the case at the time of the modelling); therefore, for each damaged asset, the estimated outage time for road access between the Lower Hutt road zone (see response road outage in Table 2) and the road zone associated with the damaged asset location was added to the repair time assigned to the damaged asset;

Table 7: Estimated repair times (days) for electricity network assets in the study area.

\begin{tabular}{|c|c|c|c|c|c|c|}
\hline \multirow[b]{2}{*}{ Asset } & \multicolumn{6}{|c|}{ Repair Time (Days) for Damage State (DS) } \\
\hline & $\begin{array}{l}\text { DS0: } \\
\text { None }\end{array}$ & $\begin{array}{c}\text { DS1: } \\
\text { Insignificant }\end{array}$ & $\begin{array}{l}\text { DS2: } \\
\text { Light }\end{array}$ & $\begin{array}{c}\text { DS3: } \\
\text { Moderate }\end{array}$ & $\begin{array}{c}\text { DS4: } \\
\text { Severe }\end{array}$ & $\begin{array}{c}\text { DS5: } \\
\text { Critical }\end{array}$ \\
\hline MV (>66kV) Substation & 0 & 0 & 0 & 0 & 4 & 4 \\
\hline LV $(<66 \mathrm{kV})$ Substation & 0 & 0 & 0 & 0 & 3 & 30 \\
\hline Transmission Towers & 0 & 0 & 0 & 0 & 2 & 2 \\
\hline Transmission Poles & 0 & 0 & 0 & 2 & 2 & 2 \\
\hline
\end{tabular}

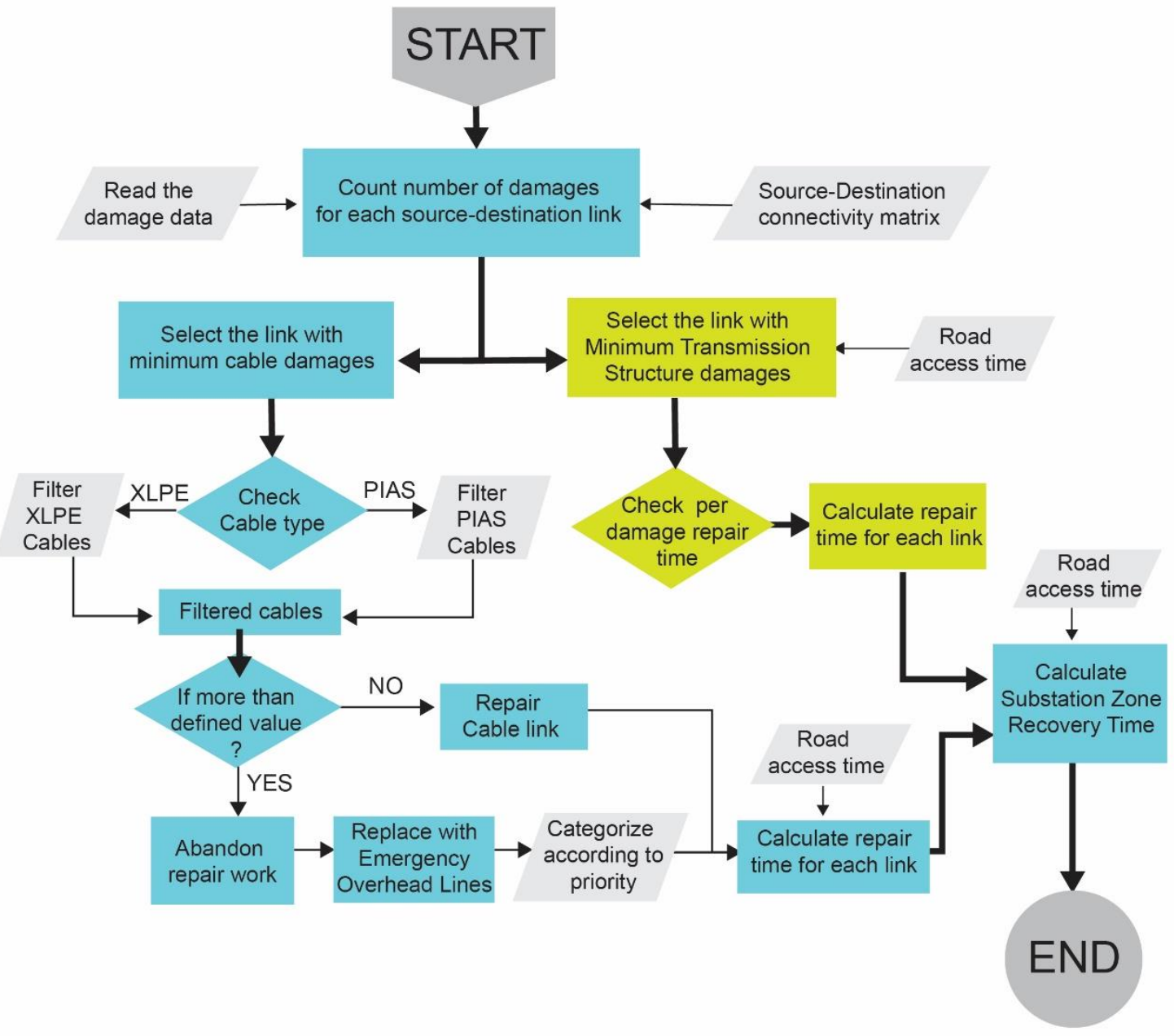

Figure 13: Flowchart showing steps taken to estimate electricity service outage at each zone substation [30]. 
Table 8: Details of the proposed electricity projects in the Preferred Investment Programme (also see Figure A1 in Appendix).

Project Proposed Work

Central Park Substation improved resilience

Phase 1: 0-7 years
Cost est. (2019): $\$ 40 \mathrm{~m}$
This project will improve the resilience of the assets contained within Central Park Substation by spreading them over a larger geographic footprint. Specifically, this project involves construction of a second Central Wellington grid exit point (GXP) substation, at an unspecified location nearby to the Central Park Substation and the associated 33kV cable connections into the Wellington Electricity (WE) network. One cable from each zone substation would be extended to the new switchboard. Assumed to be designed to code and no damage expected to Central Park or the $33 \mathrm{kV}$ cables.
Significance

This project will improve the resilience of the electricity network, in particular the supply of electricity to Wellington CBD including Parliament and the stock exchange, which are crucial for the return to Business as Usual (BAU). This project would move one transformer and half the $33 \mathrm{kV}$ switchboard to the new location, mitigating the risk of Central Park site failure. Improved resilience in the provision of electricity to Wellington Hospital will have direct health benefits. This project will support recovery of other lifelines including pump stations and the telecommunications network and will also mitigate against other risks such as fire or sabotage. This project has been identified in WE's Asset Management Plan 2017 [31].

Central Park to Frederick Street cables replacement Phase 1: 0-7 years Cost est. (2019): $\$ 5 \mathrm{~m}$

Replacement of the cables between Central Park Substation and Frederick Street Zone Substation with cross-linked polyethylene (XLPE).

This project is scheduled for implementation under WE's ongoing cable replacement programme and therefore has been included to accelerate funding.
Seismic upgrade of cables and creation of $33 \mathrm{kV}$ rings

Phase 1: 0-7 years

(33\% completed)

Phase 2: 8-14 years

(66\% completed)

Phase 3: $15-20$ years $(100 \%$

completed)

Cost est. (2019): \$160m
The seismic upgrade of $33 \mathrm{kV}$ buried cables will be undertaken, replacing oil and gas filled cables with modern solid insulated cables, $33 \mathrm{kV}$ rings will be constructed with areas in significant liquefaction zones being prioritised. These cables will perform much better in a fault event and rings will provide diversity of supply, further improving the resilience of the electricity network
This project has been previously identified in WE's Asset Management Plan and is a key enabler of a number of other infrastructure types to operate. It will benefit the entire region and have direct public health benefits through improved resilience of supply to hospitals and medical facilities. This project has been included in the programme to potentially accelerate its implementation rather than waiting for cables to reach the end of their life before requiring replacement.
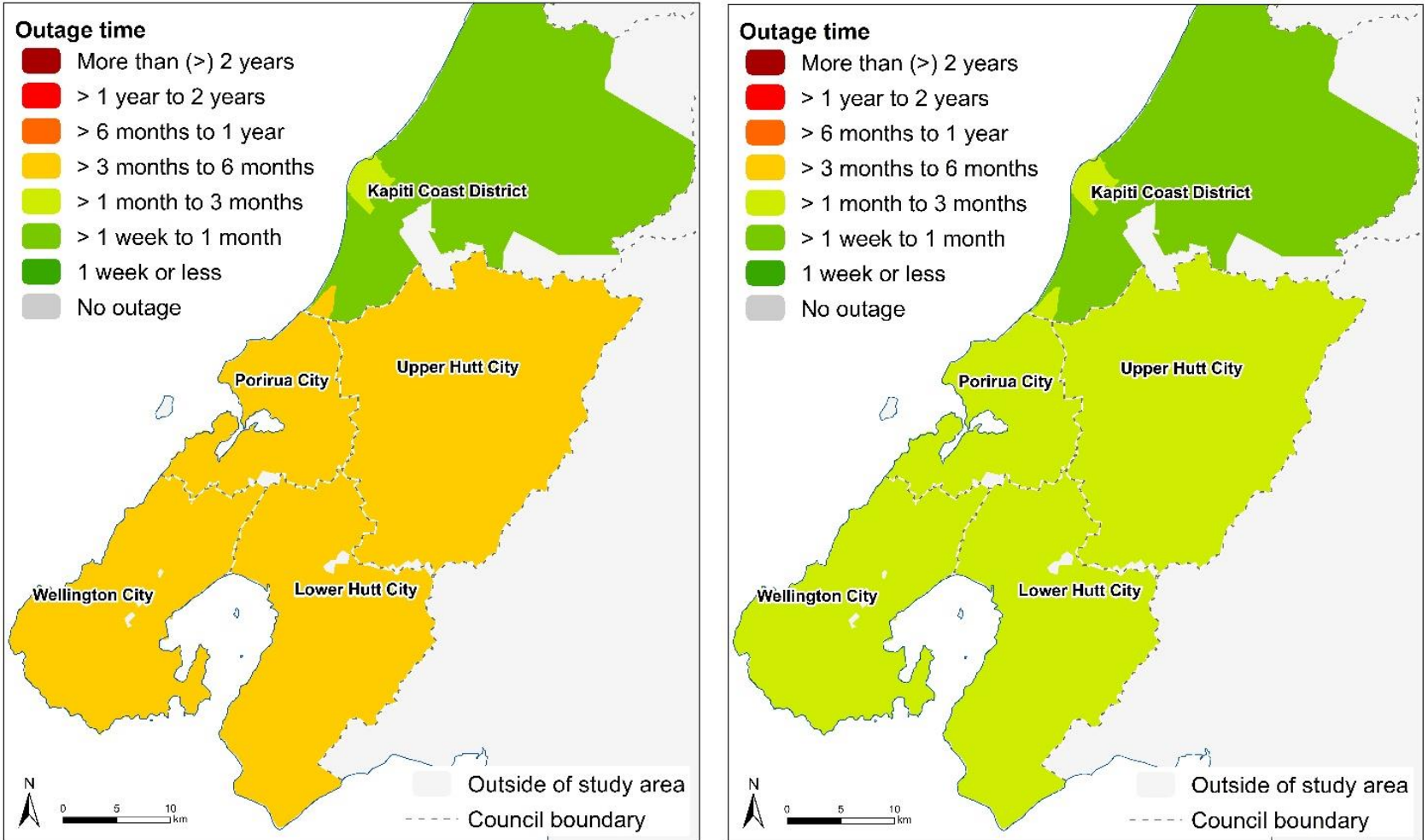

Figure 14: Electricity service outage times estimated for Base Case (left) and Improved Resilience Case (right).

3. The recovery periods of the zone substation and the intraconnected assets upstream of the zone substation were used to arrive at the outage time for electricity supply at the zone substation. The governing recovery time from all the assets was then assigned to the zone substation; and

4. Assets downstream to the zone substations were not explicitly modelled in this study. However, an allowance of 10 days is made for repairing any potential damage to such local distribution assets and was added to the outage time calculated in Step 3.
The service outage map generated for the base case is shown in Figure 14.

\section{Improved Resilience Case}

Three projects are included in the preferred investment programme as detailed below (also see Table 8). A failure risk at Central Park substation is aimed to be lowered with the first two projects implemented, and the associated proposed works included in Phase 1 of the programme. Under the third project 
below, one-third of identified $33 \mathrm{kV}$ network is planned to be strengthened in the 1st Phase, with the remaining strengthening work proposed to be completed in Phase 2 and Phase 3.

1. Improving resilience of assets at Central Park Substation the proposed works are assumed to be undertaken to meet the required Standards and can be expected to be not damaged in the scenario considered.

2. Replacement of existing buried cables between Central Park and Frederick Street - use of the proposed high capacity XLPE cables for the replacement cables can be expected to perform better than the existing cables during the earthquake. Improved performance of the cables will contribute to reduce the service outage times.

3. Seismic upgrade of cables and creation of $33 \mathrm{kV}$ rings upgrading existing $33 \mathrm{kV}$ buried cables to modern solid insulated cables will result in better seismic performance of the cables and, with proposed $33 \mathrm{kV}$ rings construction, they will together improve the resilience of the network.

The asset model developed for the base case was modified to reflect the proposed works. The fragility models assigned to the cables in the base case were re-assigned in close alignment to the cable types that will be used for the replacement cables.

Damage modelling was conducted for the improved resilience case assuming that the proposed projects are implemented before the earthquake event. The same earthquake scenario and assessment methodology applied in the base case was used for this improved case. As can be expected, the extent and severity of damage to the network, and its impact on service outages under the scenario considered is reduced (Figure 14) thus demonstrating the benefit in making the proposed resilience investments.

\section{CONCLUDING REMARKS}

Lifeline utilities support life and the economies of communities of all sizes. They are often a complex system of networks (e.g. road, electricity) in which each network depends not only on the components within its own network to function but also typically depend on other networks to successfully deliver services to communities. Failure of one network can have a cascading impact on services provided by other dependent networks. Evidence from past earthquake events have shown that when services are completely lost or operate at reduced levels for a long period of time, they can adversely impact businesses and communities. While it may not be practically possible to completely avoid the impacts, they can be reduced.

This paper discussed a major programme of works proposed to improve the resilience of lifeline utility services in Wellington and its surrounding cities. A preferred programme of investment has been proposed that comprises of 25 resilience projects (at an estimated initial capital cost of NZ\$3.9 billion) that have been carefully sequenced (to account for interdependencies) to be phase-delivered over a 20 -year period. Taken together, the projects provide interdependency, for example in that they improve access to repair broken infrastructure, ensure that power is restored sooner to the water network and telecommunications networks. The fuel, road, and electricity projects were found to provide the greatest resilience benefit to the other projects in the programme.

As part of this project, physical damage and service outage modelling on nine different lifeline utilities were conducted considering a $\mathrm{M}_{\mathrm{w}} 7.5$ Wellington Fault earthquake scenario. The assessment approach taken was explained in this paper for the key networks (i.e. road, fuel and electricity) in the region. It was demonstrated that by making targeted and integrated infrastructure investments before the next major earthquake in the region, the damage to the networks and disruption to the services the networks provide can be reduced, thereby resulting in shorter service outage times and lesser economic disruption. The temporal service outage tables and maps generated from this work formed an essential input to evaluate and demonstrate the impact of the proposed resilience investments on the regional and national economies. Furthermore, while not explicitly modelled in the project, significant social benefits could be expected to be achieved through Wellington's communities surviving and thriving after a major seismic event. This, however, needs to be confirmed by future research work.

\section{ACKNOWLEDGEMENTS}

The authors thank all the participating lifeline organisations who contributed funding, data, time and expertise to the project. These are: CentrePort, Electra, Greater Wellington Regional Council, Hutt City Council, Kapiti Coast District Council, KiwiRail, Nova Energy, Powerco, Porirua City Council, Transpower, Upper Hutt City Council, Waka Kotahi New Zealand Transport Agency, Wellington City Council, Wellington Electricity and Wellington Water. The WeLG PBC Project Steering Group is thanked for their valuable guidance and feedback at all stages of the project. Aurecon, Market Economics, Resilient Organisations, Tonkin \& Taylor Limited, Ernst \& Young Global Limited are all thanked for their collaboration on the implementation of this project. The authors gratefully appreciate valuable research and funding from many research programmes/projects from GNS Science: (a) It's Our Fault, (b) RiskScape, (c) Post-disaster Functioning of Cities, (d) Built Environment \& Performance, Social Vulnerability, Evolving Landscapes Project. The authors are also grateful to the reviewers for their thoughtful comments and efforts towards improving the manuscript.

\section{REFERENCES}

1 NZSEE (2010). "Special issue on 2010 Darfield earthquake". Bulletin of the New Zealand Society for Earthquake Engineering, 43(4). http://www.nzsee.org.nz/bulletin_index/43_4.htm

2 Tang AK (Editor) (2012). "Christchurch New Zealand Earthquake of 2010 and 2011: Lifeline Performance". Technical Council on Lifeline Earthquake Engineering Monograph No. 41, American Society of Civil Engineers, Reston, $281 \mathrm{pp}$.

3 NZSEE (2011). "Special issue on 2011 Christchurch earthquake". Bulletin of the New Zealand Society for Earthquake Engineering, 44(4). http://www.nzsee.org.nz/bulletin_index/44_4.htm

4 Holden C, Kaiser A, Van Dissen R and Jury R (2013). "Sources, ground motion and structural response characteristics in Wellington of the 2013 Cook Strait earthquakes". Bulletin of the New Zealand Society for Earthquake Engineering, 46(4): 188-195. https://doi.org/10.5459/bnzsee.46.4.188-195

5 Morris GJ, Bradley BA, Walker A and Matuschka T (2013). "Ground motions and damage observations in the Marlborough region from the 2013 Lake Grassmere earthquake". Bulletin of the New Zealand Society for Earthquake Engineering, 46(4): 169-187. https://doi.org/10.5459/bnzsee.46.4.169-187

6 Wotherspoon LM, Palermo A and Holden C (2017). "The 2016 Mw7.8 Kaikoura earthquake: An introduction". Bulletin of the New Zealand Society for Earthquake Engineering, 50(2): i-iv. http://www.nzsee.org.nz/db/Bulletin/Archive/50(2)000i.p $\underline{\mathrm{df}}$ 
7 Davies AJ, Sadashiva VK, Aghababaei M, et al. (2017). "Transport infrastructure performance and management in the South Island of New Zealand, during the first 100 days following the $2016 \mathrm{Mw} 7.8$ 'Kaikoura' earthquake". Bulletin of the New Zealand Society for Earthquake Engineering, 50(2): 271-299.

https://doi.org/10.5459/bnzsee.50.2.271-299

8 McDonald GW, Smith NJ, Ayres M, Kim J-H and Harvey E (2017). "Economic Impact of the 2016 Kaikoura Earthquake". https://transport.govt.nz/assets/Uploads/OurWork/Documents/KaikouraEarthquake-MERITReport.pdf (Accessed 05/07/2020)

9 Wellington Lifelines Group (2019). "Protecting Wellington's Economy through Accelerated Infrastructure Investment Programme Business Case. Revision 3". https://www.wremo.nz/assets/Uploads/191111Wellington-Lifelines-PBC-MAIN-20191009.pdf (Accessed 09/04/2021)

10 Kestrel Group Ltd (2011). "Resilience Lessons: Orion's 2010 and 2011 Earthquake Experiences: Independent Report". September 2011, Kestrel Group Ltd, Wellington, 42pp. https://www.oriongroup.co.nz/assets/Customers/K estrel-report-resilience-lessons.pdf

11 Sadashiva VK (2019). "Potential Earthquake and Volcanic Losses to Housing New Zealand Portfolio - 2019 Update". Consultancy Report 2019/73. GNS Science, Lower Hutt, $\mathrm{NZ}, 42 \mathrm{pp}$

12 Rhoades DA, Van Dissen RJ, Langridge RM, Little TA Ninis D, Smith EGC and Robinson R (2011). "Reevaluation of conditional probability of rupture of the Wellington-Hutt Valley segment of the Wellington Fault". Bulletin of the New Zealand Society for Earthquake Engineering, 44(2): 77-86.

https://doi.org/10.5459/bnzsee.44.2.77-86

13 Beetham RD, Cousins WJ, Craig M, Dellow G and Van Dissen R (2012). "Hutt Trunk Wastewater Earthquake Vulnerability Study". Consultancy Report 2012/234, GNS Science, Lower Hutt, NZ, 51pp.

14 Langridge RM, Ries WF, Litchfield NJ, Villamor P, Van Dissen RJ, Rattenbury MS, Barrell DJA, Heron DW, Haubrock S, Townsend DB, Cox SC, Berryman KR, Nicol A, Lee JM and Stirling MW (2016). "The New Zealand active faults database". New Zealand Journal of Geology and Geophysics 59 (1): 86-96.

https://doi.org/10.1080/00288306.2015.1112818

15 Stirling M, McVerry G, Gerstenberger M, Litchfield N, Dissen R, Berryman K, Barnes P, Wallace L, Villamor P, Langridge R, Lamarche G, Nodder S, Reyners ME, Bradley B, Rhoades DA, Nicol A, Pettinga J, Clark KJ and Jacobs K (2012). "National seismic hazard model for New Zealand: 2010 update". Bulletin of the Seismological Society of America, 102(4): 1514-1542.

16 Bradley BA (2013). “A New Zealand-specific pseudospectral acceleration ground-motion prediction equation for active shallow crustal earthquakes based on foreign models". Bulletin of the Seismological Society of America, 103(3): 1801-1822. https://doi.org/10.1785/0120120021

17 Dellow GD, Perrin ND and Ries WF (2018). "Liquefaction Hazard in the Wellington Region”. Science Report 2014/16, GNS Science, Lower Hutt, NZ, 71pp.

18 Tonkin and Taylor Ltd. (2017). "MINERVA Earthquake Loss Model". Liquefaction Module Technical Document.

19 Sadashiva VK, King AB and Matcham I (2017). "Exploring a risk evaluation tool for New Zealand state highway network national resilience project". 16th World Conference on Earthquake Engineering, 9-13 January, Santiago, Chile, Paper 3957.

20 Townsend DB, Begg JG, Van Dissen RJ, Rhoades DA, Saunders WSA and Little TA (2016). "Estimating coseismic subsidence in the Hutt Valley associated with rupture of the Wellington fault". Bulletin of the New Zealand Society for Earthquake Engineering, 49(3): 283291. https://doi.org/10.5459/bnzsee.49.3.283-291

21 Sadashiva VK, Nayyerloo M, Williams J, Heron DW, Uma SR, Horspool NA, Buxton R, Lin S-L, Lukovic B, King AB, Berryman K and Daly M (2020). "Potential benefits of implementing water network resilience projects in Wellington region of New Zealand". 17th World Conference on Earthquake Engineering, Sendai, Japan, Paper No. C002641.

22 Sadashiva VK, Mowll R, Heron DW and Lukovic B (2020). "Reducing transportation network outages through integrated infrastructure resilience investment programme". 17th World Conference on Earthquake Engineering, Sendai, Japan. Paper No. C002636.

23 King AB, Sadashiva VK, Dellow GD, Paulik R, Bell R, Smart G, Wadhwa S and Matcham I (2015). "Highway Network Risk Evaluation Tool - Proof of Concept". Consultancy Report 2015/223. GNS Science, Lower Hutt, NZ, 93pp.

24 Brabhaharan P and Mason D (2012). "Wellington Region Road Network Resilience Study". Report No. GER 2012-21. Prepared by Opus for the NZ Transport Agency, Wellington City Council, Hutt City Council, Upper Hutt City Council, Porirua City Council and Kapiti Coast District Council. September 2012. 79pp.

25 Uma SR, Sadashiva VK, Horspool N and Mueller C (2017). "Natural Hazard Loss Estimates for Z Energy Assets in Canterbury, Lower North Island, Auckland, Bay of Plenty, Gisborne, Napier and Wellington Regions". Consultancy Report 2017/29. GNS Science, Lower Hutt, NZ, 58pp.

26 King A, Rosser B, Matcham I, Dellow S, van Balegooy S and Lacrosse V (2017). "Liquefaction risk evaluation modelling for Hawkes Bay region, New Zealand". 16th World Conference on Earthquake Engineering, 9-13 January, Santiago, Chile, Paper 2970.

27 Xie L, Tang J, Tang H, Xie Q and Xue S (2012). "Seismic fragility assessment of transmission towers via performance-based analysis". 15th World Conference on Earthquake Engineering, 24-28 September, Lisbon, Portugal, 10pp.

28 Federal Emergency Management Agency (2015). "HazusMH 2.1 Technical Manual: Earthquake Model". https://www.fema.gov/media-library-data/20130726-182025045-6286/hzmh2_1_eq_tm.pdf (Accessed 27/3/2018)

29 Lin S-L, Nayyerloo M and Zhang H (2016). "Seismic performance of buried cables during the Canterbury earthquake sequence". Australasian Earthquake Engineering Society Conference, 25-27 November, Melbourne, Australia, Paper 372.

30 Uma SR, Syed Y, Karalliyadda SC and Prasanna R (2020). "Modelling Interdependencies of Critical Infrastructure Network Recovery Using a Decision Support System". Science Report 2020/18. GNS Science, Lower Hutt, NZ, 42pp.

31 Wellington Electricity (2015). "Wellington Electricity 10 Year Asset Management Plan (1 April 2016 - 31 March 2026)". Wellington Electricity, Wellington, NZ. 


\section{APPENDIX}

Table A1: Preferred Investment Programme projects. Location of the proposed works are indicated in Figure A1.

\section{Project}

Seaview Wharf seismic strengthening

Phase 1: 0-7 years

SH58/Haywards Resilience Improvements from Transmission Gully to Hutt Valley ${ }^{1}$ Phase 1: 0-7 years

Taita Gorge Access Road strengthening ${ }^{1}$

Phase 1: 0-7 years

\begin{tabular}{|c|c|}
\hline $\begin{array}{l}\text { Wadestown to Johnsonville - seismic strengthening of roads }{ }^{1} \\
\text { Phase 1: 0-7 years }\end{array}$ & $\$ 20 m$ \\
\hline $\begin{array}{l}\text { Improve resilience of airport connectivity to city network }{ }^{1} \\
\text { Phase 1: } 0-7 \text { years }\end{array}$ & $\$ 10 m$ \\
\hline $\begin{array}{l}\text { Improving resilience of Central Park Substation }{ }^{2} \text { assets } \\
\text { Phase 1: } 0-7 \text { years }\end{array}$ & $\$ 40 m$ \\
\hline $\begin{array}{l}\text { Central Park to Frederick Street cables replacement }{ }^{2} \\
\text { Phase 1: 0-7 years }\end{array}$ & $\$ 5 m$ \\
\hline $\begin{array}{l}\text { Seismic upgrade of cables and creation of } 33 \mathrm{kV} \text { rings }^{2}-\text { multiple locations } \\
\text { Phase 1: } 0-7 \text { years }(33 \% \text { completed }) \\
\text { Phase 2: } 8-14 \text { years }(66 \% \text { completed }) \\
\text { Phase 3: } 15-20 \text { years }(100 \% \text { completed })\end{array}$ & $\$ 160 \mathrm{~m}$ \\
\hline $\begin{array}{l}\text { Cross Harbour Pipeline } \\
\text { Phase 1: 0-7 years }\end{array}$ & $\$ 139 m$ \\
\hline $\begin{array}{l}\text { Prince of Wales and Bell Road Reservoir Upgrade } \\
\text { Phase 1: 0-7 years }\end{array}$ & $\$ 78 m$ \\
\hline $\begin{array}{l}\text { Silverstream Bridge Pipeline Replacement } \\
\text { Phase 1: } 0-7 \text { years }\end{array}$ & $\$ 23 m$ \\
\hline $\begin{array}{l}\text { General water supply toughening - multiple locations } \\
\text { Phase 1: } 0-7 \text { years }(33 \% \text { completed) } \\
\text { Phase 2: } 8-14 \text { years }(66 \% \text { completed }) \\
\text { Phase 3: } 15-20 \text { years }(100 \% \text { completed })\end{array}$ & $\$ 654 m$ \\
\hline $\begin{array}{l}\text { Dedicated back up power for cell towers - multiple locations } \\
\text { Phase 1: } 0-7 \text { years }\end{array}$ & $\$ 6.85 \mathrm{~m}$ \\
\hline $\begin{array}{l}\text { Port Seismic Strengthening } \\
\text { Phase 1: 0-7 years }\end{array}$ & $\$ 312 m$ \\
\hline $\begin{array}{l}\text { Better engineered road links to existing Roll-on-Roll-off (RORO) Terminal and port area }{ }^{1} \\
\text { Phase 1: 0-7 years }\end{array}$ & $\$ 71 m$ \\
\hline
\end{tabular}

Rail (NIMT Line and Hutt Valley Line) Seismic Upgrade of slopes and bridges - multiple $\quad \$ 100 \mathrm{~m}$

locations

Phase 1: $0-7$ years $(50 \%$ completed)

Phase 2: $8-14$ years (100\% completed)

Porirua Branch (pipeline) Replacement \& provision of Emergency Pumping Plant \$33m

Phase 2: 8-14 years

Carmichael to Johnsonville and Karori Pipeline - multiple works

Phase 2: 8-14 years

\begin{tabular}{ll}
\hline Porirua Low Level Zone Reservoirs - provision of additional reservoirs & $\$ 25 \mathrm{~m}$ \\
Phase 2: 8-14 years & $\$ 2 \mathrm{~m}$ \\
\hline Waterloo Water Treatment Plant improvements (liquefaction project) & \\
Phase 2: 8-14 years & $\begin{array}{l}\$ 250 \text { million to } \$ 2,200 \text { million (2018 re-evaluation summary } \\
\text { report), however for the WeLG PBC report the figure of } \\
\$ 1,062 \text { million was used }\end{array}$ \\
\hline New road: Petone to Grenada ${ }^{1}$ & $\$ 65 \mathrm{~m}$ \\
Phase 2: 8-14 years & $\$ 250 \mathrm{~m}$ \\
\hline $\begin{array}{l}\text { Cross Valley Link (new road) - SH2 to Seaview }{ }^{1} \\
\text { Phase 2: 8-14 years }\end{array}$ & $\$ 50 \mathrm{~m}$ \\
\hline $\begin{array}{l}\text { New Roll-on-Roll-off (RORO) Terminal } \\
\text { Phase 2: 8-14 years }\end{array}$ & $\$ 126 \mathrm{~m}$ \\
\hline Middleton Road retaining walls upgrade & \\
\hline Phase 3: 15-20 years & \\
\hline Waterloo Pump Station extension and new pipeline from Waterloo to Haywards &
\end{tabular}

\section{Capital Cost in NZD (2019 estimate)}

$\$ 35 m$

$\$ 24 m$

$2.5 \mathrm{~m}$

$\$ 20 m$

$\$ 247 m$

$\$ 25 m$

$\$ 2 m$

062 million was used

Additional details on roading and electricity projects: ${ }^{1}$ (see Table 3$),{ }^{2}$ (see Table 8 ) 


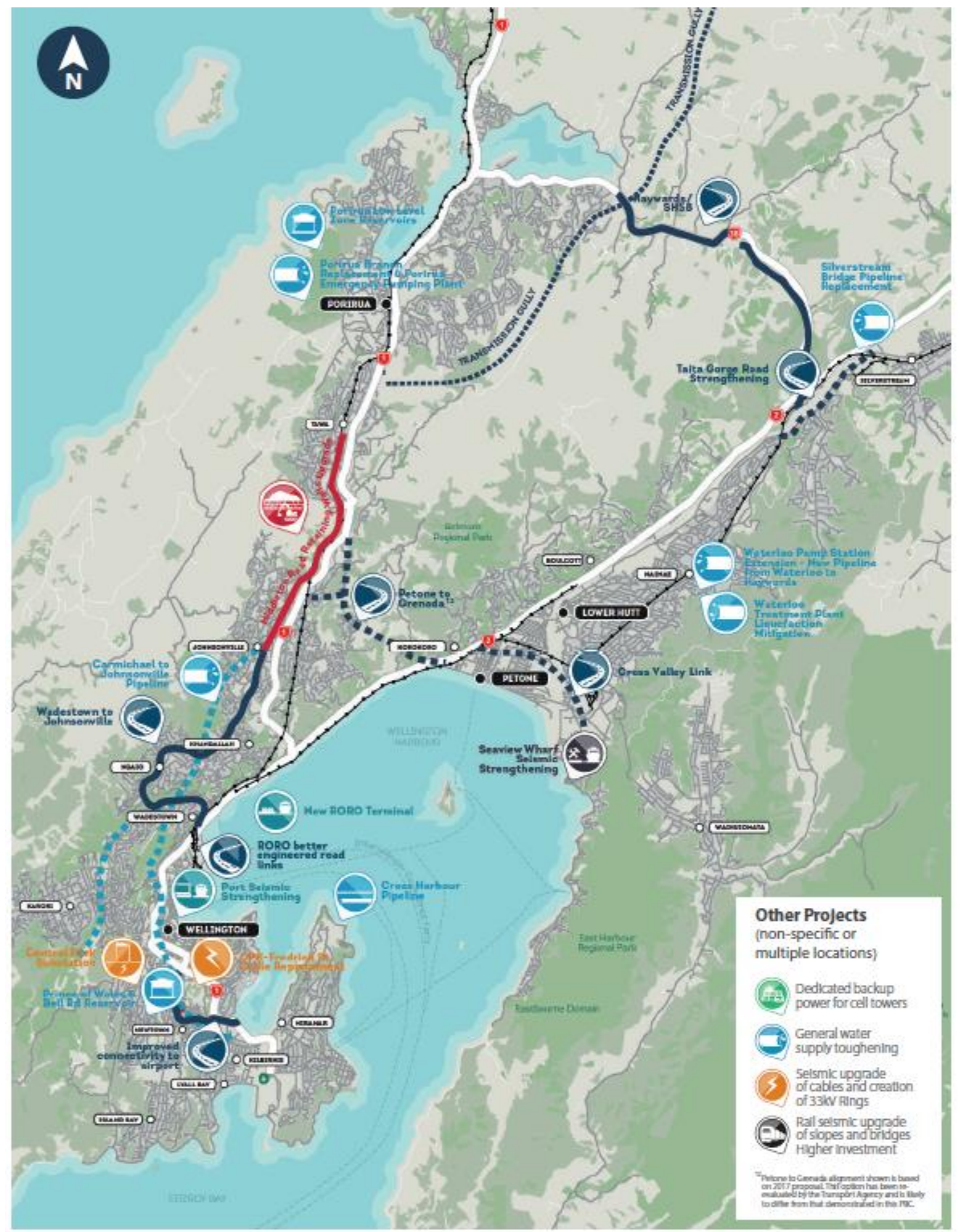

Figure A1: Schematic showing locations of the projects listed in Table A1. New construction and strengthening works for horizontal infrastructure (e.g. roads) are respectively shown by dotted and solid lines. Original map credit: Aurecon. 